\title{
DOBLE SUBSUNCIÓN, CRÍMENES DE LESA HUMANIDAD Y PRINCIPIO DE LEGALIDAD. ESPECIAL REFERENCIA AL CASO COLOMBIANO.
}

\author{
Carlos Augusto Gálvez Bermúdez.
}

\begin{abstract}
RESUMEN
El comentario muestra cómo la Corte Suprema de Justicia, Sala de Casación Penal, al condenar al excongresista Dr. César Pérez García, hace una doble subsunción de las conductas que a él se le imputaron, ora como crímenes internos ora como crímenes de lesa humanidad sin que ello se acomode a las exigencias del artículo $7^{\circ}$ del Estatuto de Roma. Además, se dice que tal forma de abordar esos fenómenos supone una violación al principio de legalidad, máxime si se acude a una normatividad internacional no existente al momento en el cual fueron cometidos los hechos, cuando los compendios normativos de entonces manejaban estructuras distintas al concepto contemporáneo, que inclusive exigían que los hechos se cometieran en medio del conflicto armado. En fin, llama la atención en el sentido de que a la hora de conceptuar la categoría de la antijuridicidad se acuda como fundamento a elementos propios del derecho natural, pues se afirma que la filosofía de los derechos humanos puede ser el cimento de un juicio netamente jurídico como lo es la tutela de bienes jurídicos legalmente protegidos.

\section{Palabras clave}

Derecho penal comparado, derecho penal internacional, derecho penal trasnacional, crímenes de lesa humanidad, clasificación de los crímenes, elemento contextual, masacre, delitos internos, doble subsunción penal.
\end{abstract}

\section{“CORTE SUPREMA DE JUSTICIA}

\section{SALA DE CASACION PENAL}

Acta número 148

Bogotá, D.C, quince (15) de mayo de dos mil trece (2013).

Finalizada la audiencia pública, la Sala de Casación Penal dicta sentencia en el juicio contra el ex congresista, doctor CÉSAR PÉREZ GARCÍA. 


\section{HECHOS}

En el año de 1988 se celebró por primera vez la elección popular de alcaldes. Una nueva fuerza que bajo el nombre de "Unión Patriótica" irrumpió en el quehacer político nacional, logró con Rita Ivonne Tobón Areiza y siete de trece concejales, constituirse en la fuerza electoral mayoritaria del municipio de Segovia, localidad del nordeste antioqueño, en donde por años habían dominado los partidos tradicionales como consecuencia de un sistema de designación de la primera autoridad local sin participación popular.

A organizaciones de ultraderecha no les agradó ese nuevo escenario y muy pronto se notificó a los segovianos de la aparición de un movimiento autodenominado "Muerte a revolucionarios del nordeste", que restauraría el orden en el municipio. En medio de esa confrontación, irrumpió en la noche del 11 de noviembre de 1988 un ejército privado que bajo el mando de Alonso de Jesús Baquero, alias "Vladimir", segó la vida a varias personas ${ }^{1}$ y afectó la integridad personal de otras ${ }^{2}$, en un acto demencial de retaliación política contra los habitantes de ese municipio.

Alias "Vladimir" le contó a la justicia tiempo después, luego de haberse comprobado su participación en ese operativo contra la indefensa población civil, que en una finca del Magdalena Medio, Henry Pérez le ordenó ejecutar ese acto que se ha dado en llamar para la historia la "Masacre de Segovia", luego de explicarle que CÉSAR PEREZ GARCÍA, un reconocido político, era el gestor de semejante acto.

\section{IDENTIDAD DEL PROCESADO}

CÉSAR AUGUSTO PÉREZ GARCÍA, natural de Remedios, Antioquia, hijo de Máximo y Leonisa, nacido el 5 de agosto de 1935, identificado con la

${ }^{1}$ Fallecieron: Adalberto Lozano Ruiz, Carlos Enrique Restrepo Cadavid, Carlos Enrique Restrepo Pérez, Diana María Vélez, Erika Milena Marulanda, Fabio Jaramillo, Fabio Sierra Gómez, Francisco William Gómez Monsalve, Gildardo Antonio Restrepo Cadavid, Guillermo Osorio Escudero, Guillermo de Jesús Areiza, Henry Alberto Castrillón, Jairo Rodríguez Pardo, Jesús Aníbal Gómez, Jesús Antonio Benitez, Jesús Antonio García, Jesús Emilio Calle Guerra, Jesús Orlando Vásquez Zapata, Jorge Luis Puerta Londoño, José Abelardo Madrid, José Alberto Osorno Betancur, José Danilo Amariles Ceballos, Juan de Dios Palacio Múnera, Julio Martín Flórez Ortiz, Libardo Antonio Cataño Atehortúa, Luis Adalberto Lozano Ruiz, Luis Ángel de Jesús Moreno San Martín, Luis Eduardo Hincapié, Luis Eduardo Sierra, María del Carmen Idárraga, María Dolly Bustamante, María Soledad Niño, Olga Agudelo Barrientos, Oscar de Jesús Agudelo, Pablo Emilio Gómez Chaverra, Pablo Emilio Idárraga Osorio, Regina del Socorro Muñoz Mestre, Roberto Antonio Marín Osorio, Robinson de Jesús María Arena, Rosa Angélica Mazo Arango, Shirley Castaño Patiño, Vidalia Orozco Saldarriaga y tres personas más no identificadas.

${ }^{2}$ Sufrieron lesiones: Mario de Jesús Villa, Johny Jaramillo Restrepo, Norbey Jiménez, Macleris de Jesús Brando Soto, Guillermo Alzate Fonnegra, Miguel Ángel Carrillo, José Antonio Palacios Bohorquez, Olga Palacios San Martín. 
cédula de ciudadanía número 2.856.396 de Bogotá, de profesión abogado, ex diputado, ex representante a la Cámara, y ex senador de la República.

\section{ACTUACIÓN PROCESAL RELEVANTE}

\section{1.- La investigación la inició la Fiscalía General de la Nación.}

2.- El 6 de julio de 1994, la Fiscalía Regional de Bogotá dispuso que se escuchara en diligencia de indagatoria a CÉSAR PÉREZ GARCÍA, la cual se llevó a cabo el 11 de septiembre de 1995 ante la Fiscalía Regional de Medellín, autoridad que el día 21 del mismo mes y año se abstuvo de imponerle medida de aseguramiento.

3.- El 19 de diciembre de 2007 el sindicado solicitó el cierre de la instrucción y el 15 de abril del año siguiente requirió la preclusión de la investigación.

4.- El 6 de noviembre de 2009 con fundamento en la decisión proferida por la Sala el 1 de septiembre del mismo año, la Fiscalía Tercera de la Unidad de Derechos Humanos, remitió el asunto por competencia.

5.- El 13 de mayo de 2010 la Sala avocó conocimiento y dispuso continuar con la investigación por tratarse de una conducta imprescriptible. ${ }^{3}$

Luego de la práctica de varias pruebas, la Sala escuchó en ampliación de indagatoria al procesado y le resolvió su situación jurídica mediante auto del 22 de julio de $2010^{4}$, con medida de aseguramiento de detención preventiva como determinador de los delitos de Genocidio y concierto para delinquir con ese fin.

En consecuencia, ordenó su captura, la cual se hizo efectiva el día 22 de julio del mismo año. ${ }^{5}$

6.- Mediante providencia del 6 de diciembre de 20106, la Sala clausuró el ciclo investigativo.

7- Luego de presentadas las alegaciones correspondientes, el 14 de marzo de $2011^{7}$ calificó el mérito del sumario, acusando a CÉSAR PÉREZ GARCÍA.

En la providencia la Corte se refirió a los hechos ocurridos el 11 de noviembre de 1988 en Segovia, los cuales tipificó como un concurso de delitos de homicidio agravado y lesiones personales, comportamientos que estimó constituían por su gravedad y sistematicidad, delitos de lesa humanidad, bajo el epígrafe de "Masacre de Segovia". Igualmente le fue imputado el delito de concierto para delinquir agravado.

\footnotetext{
${ }^{3}$ c.o. 1 folio 12.

${ }^{4}$ c. o. 2 folio 1.

${ }^{5}$ c. o. 2 folio 128 .

${ }^{6}$ c. $o .5$ folio 188 .

${ }^{7}$ c. o. 9 folio 1 .
} 
8.- El 18 de julio de 2011 se inició la audiencia preparatoria, ${ }^{8}$ en la cual se desestimaron las nulidades propuestas por la defensa y algunas pruebas solicitadas.

En síntesis, la Corte aclaró que el epígrafe que se utilizó relacionado con la "Masacre de Segovia" era ilustrativo de una situación de contexto, en la medida que la "ratio decidendi" de la acusación permite afirmar lo siguiente:

"En consecuencia, claro es que al doctor César Pérez García se le acusa en calidad de determinador por los delitos de homicidio múltiple agravado (atentado contra la vida de 44 personas), lesiones personales agravadas (atentado contra la integridad física de 32 personas) y concierto para delinquir, los cuales se enmarcan dentro del contexto de un crimen contra la humanidad que se ha categorizado como Genocidio, como una especie del género de los crímenes de Lesa Humanidad, razón por la cual, la acción penal es imprescriptible aunque la eventual pena que se pueda imponer corresponderá estrictamente al marco legal vigente interno para la fecha de ocurrencia de los hechos, esto es, a los tipos penales correspondientes a los delitos que se acaban de enunciar." 9

Esta decisión fue impugnada a través del recurso de reposición, el cual fue resuelto el 19 de julio de 2011, desestimándose los argumentos del recurrente. ${ }^{10}$

9.- La audiencia pública de juzgamiento se llevó a cabo en varias sesiones a partir del 30 de enero de 2012 y culminó el 11 de mayo del año en referencia.

\section{INTERVENCIÓN DE LOS SUJETOS PROCESALES EN LA AUDIENCIA PÚBLICA}

El Ministerio Público. La Procuraduría señala que cualquier consideración acerca de la tipicidad de la conducta quedó superada, y que lo que resta es determinar si CÉSAR PÉREZ GARCÍA es responsable como determinador de los hechos ocurridos el 11 de noviembre de 1988, conocidos como la "Masacre de Segovia", para lo cual realiza una reseña histórica del paramilitarismo en Colombia, cuáles fueron los actores del conflicto armado y cómo con sus acciones se cometieron delitos de lesa humanidad.

Señala que el país presenció la persecución y aniquilación de la "Unión Patriótica", partido que fue reconocido en 1986 por el Consejo Nacional Electoral y el cual se constituyó en su momento en la tercera fuerza política más importante del país. Ese exterminio, señala, fue consecuencia de un ataque generalizado y sistemático contra dirigentes y simpatizantes de esa agrupación, bajo la consideración de que representaba el brazo político de las Farc.

\footnotetext{
${ }^{8}$ c. o. 11 folio 3.

${ }^{9}$ Folio 82 cuaderno 11.

${ }^{10}$ c. o. 11 folio 130.
} 
Agrega que en Remedios y Segovia, municipios del nordeste antioqueño, la Unión Patriótica consiguió en las elecciones populares para elegir alcaldes por primera vez, destronar la hegemonía Liberal liderada por CÉSAR PÉREZ GARCÍA, proceso que se desarrolló en medio de una contienda hostil, rodeada de amenazas y de muertes selectivas por la acción de grupos paramilitares.

Considera que existe evidencia de nexos entre el acusado con los grupos paramilitares que le demostraron su apoyo y que fueron artífices de esas intimidaciones, prueba de lo cual sería la carta enviada por la organización ilegal a los ciudadanos de Segovia, donde abiertamente manifiestan su respaldo al mencionado en precedencia.

Estima, además, que están probadas igualmente una serie de circunstancias que indican que el partido liberal perdió el liderazgo político en el municipio de Segovia y que PÉREZ GARCÍA, máximo líder de ese grupo, cedía de esa manera su poder y hegemonía, de ahí que tal situación explica la razón por la cual encontró una causa común con la estructura ilegal paramilitar que ejecutó la operación criminal en la citada población.

En ese sentido, la declaración de Alonso de Jesús Baquero, alias "Vladimir", miembro y líder del aparato paramilitar que consumó la acción delictiva, señaló en detalle cómo se planeó y ejecutó el operativo, a los determinadores y autores materiales de la denominada "Masacre de Segovia", entre los que mencionó al procesado.

Pero no solamente "Vladimir" fue quien le atribuyó un rol preponderante como determinador de los hechos a aquél, pues esa afirmación tiene un gran soporte en otras pruebas testimoniales, documentales, y en publicaciones de libros y del diario El Tiempo, que denotan que las acusaciones en su contra provienen de diferentes fuentes que convergen a demostrar la responsabilidad del procesado, el ejército y los paramilitares en lo acaecido el 11 de noviembre de 1988.

Por lo tanto, el Señor Procurador considera que el análisis de las pruebas en su conjunto permite afirmar que existe certeza de la participación del procesado como determinador de los graves hechos que se le imputan, sucedidos en medio de un contexto político conflictivo que desembocó en la conocida "Masacre".

Asimismo asegura que está probada la pérdida de liderazgo político de CÉSAR PÉREZ GARCÍA, su vinculación con el grupo paramilitar que se enfrascó en el exterminio de la Unión Patriótica, y la manera como este grupo ilegal con el respaldo del Ejército Nacional gestó la matanza.

Todo ello conjugado con la diciente versión de alias "Vladimir" y otros líderes paramilitares que dan razón de los nexos del procesado con grupos ilegales, condujeron al Señor Procurador a deprecar que se profiera sentencia de condena en contra del procesado. 
La Parte Civil. La representante de la parte civil solicita que se condene al procesado como determinador de los delitos por los que se le juzgó e imponga la pena máxima que corresponda a la gravedad de los mismos.

Considera que el delito de lesiones personales ha debido tipificarse como un concurso de tentativas de homicidio. Aun así, esa conducta, los homicidios y el concierto para delinquir, delitos por los cuales fue acusado el sindicado, deben ser apreciados como crímenes de lesa humanidad a la luz del derecho penal internacional de los derechos humanos, en la medida que son parte de un conjunto de hechos sistemáticos o generalizados contra militantes de la Unión Patriótica.

En ese sentido, afirma que si bien para el momento de comisión de la conducta formalmente no existía ningún tipo penal que denominara crimen de lesa humanidad a ataques masivos y generalizados; el Estado Colombiano, por lo menos desde 1950, suscribió los hoy conocidos como principios del derecho internacional de los derechos humanos, compilados en la resolución 95 de la Organización de Naciones Unidas de ese año, instrumentos que permiten por su especial gravedad, considerar delitos de la legislación común como crímenes de lesa humanidad por su sistematicidad y generalidad.

Con esa finalidad hace un recuento de innumerables delitos cometidos contra militantes de la "Unión Patriótica", de la persecución a sus integrantes y de su exterminio por razones ideológicas, para concluir que la prueba de su gravedad fue que ese dato histórico llevó a incluir expresamente en la legislación penal Colombiana la incorporación del "Genocidio Político" como delito indicativo de graves infracciones contra los derechos humanos.

A su juicio, documentos y testimonios señalan a CÉSAR PÉREZ GARCÍA como determinador de la "Masacre". Así, la carta abierta a los ciudadanos de Segovia por parte del Movimiento Muerte a Revolucionarios del Nordeste donde se le menciona como persona afín con ese grupo; la declaración de alias "Vladimir", el ejecutor material de aquella, quien lo sindica de haber sido el determinador de la misma. Y no faltan testimonios de paramilitares como Iván Roberto Duque y Fredy Rendón, quienes se refieren a las relaciones que tenía PÉREZ GARCÍA con grupos ilegales y en especial con Henry Pérez, uno de los artífices del operativo en Segovia.

Como hecho indiciario se encuentran las declaraciones de los habitantes de Segovia que conocían los antecedentes de la "Masacre", la intolerancia política e ideológica entre los diversos actores del conflicto, que permite apreciar los hechos ocurridos en Segovia la noche del 11 de noviembre de 1988 como una expresión de violencia sistemática y generalizada e inferir la participación del acusado como determinador.

La Defensa y el vocero del procesado. Los alegatos del vocero y el defensor tienen un mismo hilo conductor, por lo cual se consignará lo expuesto por ellos en un resumen común. 
Discuten la calificación jurídica de la conducta, pues en su criterio no existe claridad acerca de cuál es el comportamiento que desde el punto de vista jurídico se le imputa a su defendido.

En su criterio, la calificación jurídica en la diligencia de indagatoria dista de la que se le imputó al resolver la situación jurídica, pues en esta se le atribuyeron los delitos de genocidio y asociación para cometer genocidio; y de la muy distinta consignada en la resolución de acusación, en la cual se le acusó como presunto determinador de la "Masacre de Segovia", en la que perdieron la vida medio centenar de personas e innumerables resultaron heridas, así como daños materiales, hechos considerados como un crimen de lesa humanidad.

En ese orden, cuestionan la falta de precisión de los hechos jurídicamente relevantes por los cuales se llamó a juicio a su defendido y critican que no se haya señalado frente a cuáles homicidios, lesiones o daños que se produjeron en esos hechos actuó el doctor PÉREZ GARCÍA como determinador.

Con todo, asumen que la cuestión fáctica está definida y a partir de ese punto de vista censuran la prueba de cargo y fundamentalmente el testimonio de Alonso de Jesús Baquero Agudelo, alias "Vladimir", declaración acerca de la cual formulan una serie de consideraciones para indicar que se trata de un testigo de oídas, que lo que conoce acerca de la participación del doctor CÉSAR PÉREZ GARCÍA es al parecer lo que supuestamente otros le dijeron.

Según eso, un testigo de oídas o de referencia es inadmisible como prueba de responsabilidad e inclusive la ley 906 de 2004, aplicable por virtud del principio de favorabilidad, prohíbe que una sentencia pueda fundamentarse en ese tipo de pruebas. Sin embargo, más allá de esas consideraciones, es un hecho inobjetable que la declaración de alias "Vladimir" es de una fragilidad probatoria inocultable por la manera como tuvo conocimiento de la improbable participación del acusado en semejantes comportamientos.

En efecto: Con las absurdas aseveraciones del testigo se pretende afirmar que el incriminado tuvo nexos con los paramilitares y que buscó apoyo de grupos ilegales para llevar a cabo la "Masacre" de Segovia, en retaliación contra los habitantes de un municipio que de tiempo atrás había sido su fortín político; cuestión que a juicio de la Corte se reafirmaría con el manifiesto atribuido al movimiento "Muerte a revolucionarios del Nordeste", creado a raíz del descalabro político del grupo que el procesado lideraba en Segovia y en el cual se mencionaba a éste como uno de sus líderes.

A juicio de la defensa esas afirmaciones no tienen asidero ni en la realidad ni en el proceso, y sin embargo se ha querido dar apariencia de certeza a una cuestión fáctica que según se demostró no tiene razón de ser. No existió descalabro político, ni el grupo de CÉSAR PÉREZ GARCÍA fue derrotado estruendosamente, ni mucho menos fue enemigo de la Unión Patriótica, 
pues propició alianzas al interior del concejo con el fin de elegir a un personero de esa colectividad de izquierda. De manera que el acusado no podía gestar la creación de ningún grupo ilegal por un acontecimiento que no ha existido sociológicamente como hecho político, ni asumir venganzas contra quienes fueron sus aliados en concretos procesos gubernamentales.

En ese sentido concluyen que si a la pérdida de las elecciones del candidato liberal para la alcaldía de Segovia se le quiere dar la connotación de indicio de móvil para delinquir, cuál sería la regla de la experiencia que se tomaría en cuenta para inferir la autoría del incriminado, sobre todo si está probado que el sindicado no fue enemigo de la izquierda sino aliado de la misma.

Por todo ello, la defensa sostiene que la acusación tiene como único fundamento la declaración de Alonso de Jesús Baquero, alias "Vladimir", porque ningún otro medio de prueba avala ese artificioso testimonio. Este proceso empieza y termina con la declaración de oídas del mencionado individuo.

Aparte de la declaración del últimamente aludido, el expediente carece de cualquier posibilidad de demostrar con la seriedad que se requiere, la participación y responsabilidad del imputado. Ni siquiera, resalta la defensa, la acción se ejecutó contra militantes de la Unión Patriótica, para sostener que el móvil fue una respuesta contra sus militantes, pues si algo está claro es que los muertos no eran activistas de ese grupo político y que sólo uno pertenecía a la agrupación. Es más, si bien es cierto que ese partido fue objeto de persecución a nivel nacional, su exterminio no ocurrió en Segovia. Y tampoco fue el procesado quien con la finalidad de arrasar con la Unión Patriótica entró en contacto con los paramilitares para ejecutar los hechos investigados.

De otra parte, quienes rindieron testimonio expresaron que el enjuiciado no se llenaba de odios en las derrotas y no era engreído en los triunfos. Asumía las primeras y perseveraba para recuperar el poder incluso con alianzas; siempre manejó la contradicción civilizadamente y no se puede dudar, como se hace en la resolución de acusación, que propició alianzas entre los liberales y la Unión Patriótica.

Aun así, se ha querido atribuirle odio hacia sus adversarios y estigmatizarlo con posiciones políticas que no corresponden a su ideario, todo con fundamento en un editorial del diario El Tiempo, relacionado con su oposición al proyecto de indulto para el M-19. Ese tema por lo demás no guarda ninguna relación con la imputación que se le formuló y no se entiende por qué se aludió al mismo en la acusación, siendo que el procesado nunca estuvo en lo sustancial en desacuerdo con ese proyecto del cual fue ponente en la Cámara.

Como la declaración de alias "Vladimir" siempre ha estado en entredicho y las referencias de contexto y los indicios del móvil para delinquir son insuficientes para condenar al doctor PÉREZ GARCÍA, tardíamente se trajo 
al proceso la declaración de Iván Roberto Duque, alias "Ernesto Báez" y de Fredy Rendón Herrera, alias "El Alemán", dos confesos paramilitares que fueron especialmente controvertidos por la defensa y cuya credibilidad quedó en entredicho.

En últimas, lo único que queda es la declaración de alias "Vladimir", que sólo se explica por su interés de obtener beneficios y rebajas de pena por los incontables crímenes con los que bañó de sangre a todo el país. Por eso hizo de su dudoso arrepentimiento un negocio para seguir acabando, no ya con la vida, sino con la dignidad, el buen nombre, la honra y la libertad de gente inocente como el incriminado.

Ahora, el material probatorio que tuvo en cuenta la Corte para la formulación de acusación, si bien le sirvió a la Sala para elaborar el pliego de cargos bajo el parámetro de la exigencia de un conocimiento probable acerca de la responsabilidad del acusado, actualmente se ofrece insuficiente para llevar a la certeza que permita dictar una condena en contra de CÉSAR PÉREZ GARCÍA.

Pero si la Corte persiste en otorgarle credibilidad al único testigo de oídas y de referencia, tampoco en ese improbable supuesto podría proferir una sentencia condenatoria, porque no se conseguiría la certeza legal que como resquicio de la tarifa legal de pruebas negativa mantiene el artículo 381 de la Ley 906 de 2004, aplicable por favorabilidad a este caso, al establecer el mandato de que "la sentencia condenatoria no podrá fundamentarse exclusivamente en pruebas de referencia", en la medida que las imputaciones del único testigo de cargo, se basan en lo que supuestamente le habría comunicado Henry Pérez, siendo esta alusión la exclusiva prueba en contra del procesado.

Por lo anterior, el defensor y el vocero, solicitan que al no existir prueba idónea y suficiente para llegar a afirmar con un conocimiento más allá de toda duda, que el doctor CÉSAR PÉREZ GARCÍA es responsable de las conductas punibles por la cuales fue llamado a juicio, se profiera sentencia absolutoria por los cargos que le fueron imputados.

\section{CONSIDERACIONES DE LA CORTE}

Primero. Competencia. El tema se encuentra suficientemente dilucidado en este asunto, pero se reitera que con fundamento en los artículos 180 y 235 de la Constitución Política y 75, numeral 7 de la Ley 600 de 2000, la Sala de Casación Penal conoce de los procesos penales que se adelanten contra congresistas, tanto en la fase de la investigación como en la del juicio, siempre que la conducta punible que se les atribuya tenga relación con su función.

Según lo certificó el 20 de abril de 1994 el Sub secretario General de la Cámara de Representantes, CÉSAR AUGUSTO PÉREZ GARCÍA tomó posesión del cargo de representante a la cámara para los periodos constitucionales 
1974-1978, 1982-1986, 1986-1990. 1990-1994 y 1991-1994, lo cual le otorga la competencia a la Sala de Casación Penal, en el entendido que existe una relación de imputación concreta entre los hechos investigados con el fin de consolidar a como fuera su hegemonía política, cuestión sin duda en la que influyó o de la que se valió el procesado, la función oficial desempeñada en ese momento.

Por lo mismo, la Sala reafirmó su competencia en la Audiencia Preparatoria llevada a cabo el 18 de julio de 2011, en la cual reiteró que:

"la relación del delito con la función pública tiene lugar cuando se realiza por causa del servicio, con ocasión del mismo o en ejercicio de funciones inherentes al cargo; esto es, que la conducta tenga origen en la actividad congresional, o sea su necesaria consecuencia, o que el ejercicio de las funciones propias del congresista se constituya en medio y oportunidad propicia para la ejecución del punible, o que represente un desviado o abusivo ejercicio de sus funciones." 11

En consecuencia, la Sala, conforme lo ha expresado en el curso del proceso y ahora lo reitera, es competente para dictar el fallo de mérito en este proceso.

Segundo. De acuerdo con el artículo 232 de la ley 600 de 2000, "no se podrá dictar sentencia condenatoria sin que obre en el proceso prueba que conduzca a la certeza de la conducta punible y de la responsabilidad del procesado."

Pues bien: Conceptualmente la expresión "conducta punible" que se emplea en el artículo citado, se refiere no a la comprobación del hecho como manifestación fenomenológica o un dato óntico que desde el punto de vista causal transforma el mundo exterior, sino a un juicio de adecuación típica de una conducta que lesiona o pone en riesgo un bien jurídico tutelado por la ley.

La Sala, a partir de esa noción, responderá las apreciaciones de la defensa en torno al desvalor del comportamiento, a los juicios provisionales que se han realizado en el curso del proceso y a las implicaciones por su configuración como delito de lesa humanidad.

En efecto: La defensa pone en tela de juicio la calificación jurídica de la conducta por la modificación que ha sufrido desde cuando el procesado fue vinculado al proceso, y estima que ni aún en la resolución de acusación se precisó con la singularidad que demanda un adecuado ejercicio del derecho de defensa, el comportamiento y las implicaciones jurídicas de la conducta por la cual PÉREZ GARCÍA fue convocado a juicio.

La Corte, por supuesto, no ignora que la calificación jurídica, mas no la imputación fáctica, ha sido objeto de modificaciones durante el trámite, todas explicables desde el punto de vista de la teoría del proceso que

${ }^{11}$ Corte Suprema de Justicia, radicado 31.653, auto de septiembre 1 de 2009. 
concibe la adecuación típica como juicio provisional ${ }^{12}$, sujeta a variación de acuerdo con la dinámica de la investigación e incluso a interpretaciones de la norma penal desde una visión que, en este caso, se hace con fundamento en principios que la Constitución de 1991 incorporó al orden interno y que al momento de definir la situación jurídica, la fiscalía no tuvo en consideración. ${ }^{13}$

Lo expuesto acerca de la provisionalidad jurídica de la conducta, no es extraño en atención a que como método, entre estructuras formales y conceptuales, el proceso penal es un conjunto de actos sucesivos que a su vez dan inicio a otros, en el marco de una secuencia lógica y dialéctica destinada a la definición progresiva y vinculante de su objeto.

Empero, con fundamento en la supuesta inmutabilidad de la calificación jurídica provisional, el defensor denuncia una especie de infracción al derecho de defensa originada en su parecer en la incongruencia entre la resolución de acusación y otras decisiones que no se consideran leyes del proceso, tales como la definición de la situación jurídica o la que dispuso asumir la competencia. Sin embargo, esta apreciación es inadmisible, por la provisionalidad de la calificación jurídica de la conducta, ${ }^{14}$ y porque lo indispensable es que entre el acto condición - acusación - y la sentencia como acto final, exista congruencia fáctica y jurídica y se determine claramente el núcleo fáctico de la acusación, cuestión que por supuesto está por fuera de toda discusión.

En ese orden de ideas, la Sala quiere reafirmar la dimensión fáctica y jurídica del comportamiento que se imputa al doctor PÉREZ GARCÍA, desde la perspectiva de una interpretación que congloba los principios del derecho penal internacional y los de orden interno, teniendo como marco la necesaria tensión entre las garantías procesales debidas a los sujetos procesales y las definiciones de justicia que la sociedad en la hora actual de los derechos humanos reclama, según quedó plasmado entre otras decisiones en la audiencia preparatoria en la que se negó la petición de

${ }^{12}$ El artículo 338 de la ley 600 de 2000, dispone: "Formalidades de la indagatoria...A continuación se le interrogará sobre los hechos que originaron la vinculación y se le pondrá de presente la imputación jurídica provisional."

El artículo 342 de la misma ley dispone..."Ampliación de indagatoria... También se ampliará la indagatoria cuando aparezcan fundamentos para modificar la imputación jurídica provisional".

${ }^{13}$ La fiscalía al resolver la situación jurídica mediante medida de aseguramiento calificó la conducta como un concurso de conductas de homicidio y lesiones personales.

${ }^{14}$ El artículo 398 de la ley 600 de 2000, dispone en su numeral $3^{\circ}$, que la calificación jurídica es provisional; y el artículo 404 idem, confirma ese postulado, al dispone que: "Concluida la práctica de pruebas, si la calificación provisional dada a la conducta punible varió por error en la calificación o prueba sobreviniente respecto de un elemento básico estructural del tipo, forma de coparticipación o imputación subjetiva... (se resalta) 
nulidad solicitada por la defensa y en la cual se determinó de manera clara y precisa la cuestión fáctica y los alcances jurídicos de la imputación.

Véase: A partir de la incorporación de los Tratados Internacionales de Derechos Humanos a la Constitución Política, sus principios se convierten en parámetros vinculantes de interpretación de los derechos y deberes constitucionales. Por lo tanto, bajo esa consideración se deben apreciar los postulados básicos del derecho penal interno sobre los cuales se ha construido la legitimidad del derecho de penar - entre ellos el de legalidad e irretroactividad de la ley -, y las normas de derecho internacional que se refieren a los compromisos materiales de justicia, verdad y reparación ante graves infracciones contra derechos humanos fundamentales. ${ }^{15}$

En ese contexto se piensa que puede ser contradictorio que en aras de la justicia se cuestionen en su nombre principios del derecho penal demoliberal; sin embargo, esa antinomia sólo puede ser admisible a partir de una elaboración que tiene en cuenta la lectura de los textos legales desde una visión positivista que mira más al trazo linguístico de la ley que a la realización material de principios y valores superiores. ${ }^{16}$ En cambio, "por la imperatividad de las normas humanitarias y su integración en el bloque de constitucionalidad... el Estado colombiano debe adaptar las normas de inferior jerarquía del orden jurídico interno a los contenidos del Derecho Internacional Humanitario con el fin de potenciar la realización material de dichos valores", lo cual implica que principios del derecho penal tradicional se afecten con mayor intensidad en aras de la realización de otros de mayor relevancia,

15 "... la toma en consideración de los principios y derechos incorporados en el bloque es necesaria, pues en el sistema de fuentes colombiano la constitución es norma de normas y debe aplicarse de manera preferente, por lo que el operador jurídico no solo debe inaplicar las normas contrarias a la Carta sino que, además, debe interpretar las leyes desde los principios y valores constitucionales. Y cuando se habla de la Constitución pues debe entenderse no solo el texto constitucional sino además los derechos y principios que se encuentran incorporados al Bloque de Constitucionalidad." Cfr. Bloque de Constitucionalidad. Derechos Humanos y proceso penal. Uprimmy Yepez, Rodrigo, pag. 65.

${ }^{16}$ La Corte ha señalado al respecto lo siguiente: "Desde 1991, por fuerza de la normativización de la Constitución que antes se consideraba como un tema esencialmente político, la interpretación del derecho dejó de ser un problema de mera hermenéutica o de lógica de buena voluntad, razón por la cual hoy en día la ley solo puede tener sentido en la medida en que sus fórmulas realicen los valores y principios del texto Superior y los tratados internacionales sobre derechos humanos que conforman el bloque de constitucionalidad.

"Desde ese punto de vista, los principios, las categorías dogmáticas y los sistemas procesales no pueden considerarse a partir de interpretaciones que aíslen las normas que los definen para rescatar su sentido literal, sino desde sus fines constitucionales, de los cuales se destaca el de la construcción de un orden justo (Preámbulo Constitucional)." Cfr, Sentencia de Casación del 20 de octubre de 2005, radicado 24.026. 
como el de protección de la dignidad humana, fundamento de los Estados civilizados. ${ }^{17}$

En consecuencia, la incorporación de cláusulas internacionales de derechos humanos que giran en torno a la dignidad del ser humano como universo social y concepto ético, permiten una lectura distinta de los principios del derecho penal tradicional y un mayor nivel de protección penal ante graves atentados contra derechos humanos fundamentales, para no dejar de cumplir por defecto el principio de proporcionalidad. En ese sentido, es posible mantener la tipificación de la conducta y la pena vigente al momento de ejecución de la conducta y el desvalor de la misma pero apreciado en el momento de su persecución penal, con lo cual se articula el principio de legalidad penal tradicional y los cometidos de verdad, justicia y reparación, tan en la base del lenguaje del derecho penal internacional.

Desde este punto de vista es posible conferirle a delitos que en el ámbito del derecho penal común se denominan "homicidios" o "lesiones personales", la categoría de delitos de lesa humanidad, tanto más si para la época de su comisión Colombia ya había suscrito tratados que acentúan la sistematicidad y generalidad del ataque como criterios diferenciadores entre un delito común y conductas que en el nivel de la macro criminalidad afectan de manera superlativa los derechos humanos. ${ }^{18}$

17 "Los principios no son normas que establezcan exactamente lo que debe hacerse, sino normas que exigen que 'algo sea realizado en la mayor medida posible, dentro de las posibilidades jurídicas y reales existentes. El ámbito de lo jurídicamente posible está determinado por principios y reglas que juegan en sentido contrario." Cr., Carlos Bernal Pulido. El neo constitucionalismo y la normatividad del derecho. Ed. Externado de Colombia. 18 "...Colombia hace parte de ese acuerdo ecuménico para la lucha contra la impunidad frente a las más graves violaciones a los derechos humanos y al Derecho Internacional Humanitario. Su compromiso se refleja en el hecho de ser parte de los principales instrumentos internacionales que recogen el consenso internacional en esta materia y que han servido de base para la creación de la Corte Penal Internacional. Entre otros: i) Convención para la Prevención y Represión del Genocidio de 1948, aprobada por la Ley 28 de 1959; ii) Convención Internacional sobre la eliminación de todas las formas de discriminación racial, aprobada por la Ley 22 de 1981; iii) Convención contra la Tortura y otros tratos crueles, inhumanos o degradantes, aprobada como legislación interna por la Ley 76 de 1986; iv) Pacto Internacional de Derechos Civiles y Políticos y Protocolo Facultativo aprobada por la Ley 74 de 1968; v) Convención Americana sobre Derechos Humanos, aprobada por la Ley 16 de 1972; vi) Los Cuatro Convenios de Ginebra del 12 de agosto de 1949, incorporados a nuestro ordenamiento interno mediante la Ley 5 de 1960: Convenio I, para aliviar la suerte que corren los heridos y enfermos de las fuerzas armadas en campaña; Convenio II, para aliviar la suerte que corren los heridos, los enfermos y los náufragos de las fuerzas armadas en el mar; Convenio III, relativo al trato debido a los prisioneros de guerra; Convenio $I V$, relativo a la protección debida a las personas civiles en tiempo de guerra; vii) Protocolo I Adicional a los Cuatro Convenios de Ginebra de 1949, aprobado como legislación interna por la Ley 11 de 1992; viii) Protocolo II Adicional a los Cuatro Convenios de Ginebra de 1949, aprobado como legislación interna por la Ley 171 
Claro, porque según lo ha definido la Sala, un delito de homicidio se cataloga crimen de lesa humanidad, no por la gravedad intrínseca que una conducta de tal naturaleza conlleva o por la importancia individual de la víctima, sino por la sistematicidad de su ejecución que en muchos casos devela una compleja operación criminal, que en este caso tuvo como objetivo el grupo político de la Unión Patriótica. ${ }^{19}$ En eso no hay duda: la "Masacre de Segovia" no es un acontecimiento que se pueda separar de lo ocurrido en esa época en el contexto nacional, dado que se constituye en un episodio más de un conjunto de acciones que llevaron incluso al asilo a muchos dirigentes con el fin de salvar sus vidas, entre ellas la misma Rita Ivonne Areiza, ex alcaldesa del municipio escenario de los hechos.

La sistematicidad como componente esencial de la acción en el lenguaje de la infracción a los derechos humanos la ilustra con propiedad Hernán Mota Mota - miembro de ese partido y ex representante a la Cámara, exiliado por la persecución de que fue objeto -, como el epílogo de una serie de atentados contra ese grupo político, o Aída Abella, también asilada por su pertenencia a la exterminada Unión Patriótica, pese a que la totalidad de los muertos no pertenecían a esa colectividad.

En ese sentido, Aída Abella señaló:

“... pero en el Meta era impresionante, nos asesinan al compañero Pedro Nel de la mano de su hija de nueve años. El la llevaba todos los días al Colegio, todavía no la había soltado de la mano, cuando lo asesinan ahí a la entrada del Colegio. Por supuesto que eran completamente coordinados, ensañados...

... Haber en Antioquia no me acuerdo si fue el compañero Valencia, si fue en esa elección o fue en la otra, tal vez de todas maneras en esas elecciones empezaron a matarnos los concejales que salieron elegidos y el departamento de Antioquia fue, golpeadísimo, es imposible acordarse de cuáles eran los concejales que nos mataban. Pero yo si quiero hacer un capítulo con lo de Antioquia, con los planes "Retorno", que fue otro de los planes, bueno pero un plan muy especial que fue el plan "Cóndor"20

de 1994; ix) Convención sobre la represión y castigo del Apartheid aprobada por la Ley 26 de 1987; x) Convención Americana contra la Desaparición Forzada, incorporada a nuestro ordenamiento interno mediante la Ley 707 de 1994.

19 "El carácter generalizado del ataque implica que debe ser masivo, frecuente o lo que es igual, dirigido contra una multiplicidad de víctimas, lo cual implica que la víctima es colectiva: el grupo objeto del ataque, de ahí que se emplea la palabra 'población', es decir, "el conjunto de personas que habitan la tierra o cualquier división geográfica de ella, o el conjunto de individuos de la misma especie que ocupan una misma área geográfica", de manera que quienes cometen crimenes contra la humanidad tienen por objetivo a individuos sobre una base colectiva o no individualizada." Cfr, Sentencia del 14 de agosto de 2012, radicado 36.981 ${ }^{20}$ Declaración agosto 18 de 2010, folio 257 C.O. 2. 
“... [la] masacre de Segovia fue un castigo en mi opinión a la población como resultado del ascenso electoral y político de la Unión Patriótica.... A mí me parece que es una relación muy elemental, seguramente si no hubiéramos ganado la alcaldía, si no hubiéramos alcanzado los siete escaños de los trece que conforman el concejo municipal de esa localidad, seguramente no hubiéramos sido objeto de la matanza de que fuimos víctimas y no se hubiera perpetrado la masacre en Segovia. Justamente fue por la presencia, por el ascenso electoral, social y político de la UP, como ocurrió en las demás regiones, como ocurrió en los Llanos orientales, como ocurrió en el Magdalena medio, como ocurrió en Santander, en el Tolima, en todas las partes donde tuvimos una destacada presencia como nueva fuerza política que irrumpe en el panorama nacional y local, manera que yo señalaba esto como un antecedente, como un registro histórico de las circunstancias más generales que rodean la masacre. Es un hecho objetivo que la Unión Patriótica ganó la alcaldía en esa municipalidad donde se produjo esa matanza, la masacre..." 21

Es más, la Corte Interamericana en decisión del 26 de mayo de 2010 se refirió a la sistematicidad del ataque como elemento central de acciones de las que fueron víctimas miembros de la Unión Patriótica, lo cual no deja dudas de la estructura y generalidad del ataque, elemento esencial en la configuración del delito de lesa humanidad. ${ }^{22}$

En efecto, según lo ha explicado la Corte, a la hora de establecer principios en el caso de graves infracciones a los derechos humanos, los crímenes de lesa humanidad están asociados más que con la existencia de un conflicto armado o con la gravedad inherente de una determinada conducta, con la sistematicidad a manera de elemento material del ataque, y con el conocimiento como componente subjetivo de la acción ${ }^{23}$, características

${ }^{21}$ Declaración de Hernán Motta Motta, Cuaderno original 4 folio 44.

${ }^{22}$ En la sentencia mencionada, la Corte Interamericana en el caso Manuel Cepeda vs. Colombia, señaló: "En las fuentes disponibles no se encuentran cifras inequívocas sobre el número de personas víctimas de la violencia contra la UP. En 1995 los relatores especiales de Naciones Unidas sobre tortura y ejecuciones extrajudiciales, sumarias o arbitrarias, habian señalado que desde 1985 la UP había perdido 'a más de 2000 miembros, con inclusión de un senador, tres diputados de la Cámara baja y varios alcaldes y consejeros municipales, todos los cuales han sido asesinados por motivos políticos'... De un documento elaborado en 2008 para el programa Presidencial de Derechos Humanos de la Vicepresidencia de la república surge que, en el periodo 1984 1993, 540 homicidios corresponden a miembros de la UP con respecto al total de víctimas fatales y no fatales de violencia politica entre 1984 y 1994, pues en promedio, las víctimas de la UP representan el 40\% del total; aunque para los años 1986 y 1987 llegaron a representar casi el 60\% del total de las víctimas...."

23 "...el Estatuto de Roma de la Corte Penal Internacional, reitera la independencia del crimen de lesa humanidad con el conflicto armado, cualquiera que este sea, y determina su existencia a partir de las conductas enumeradas en el artículo $7^{\circ}$, siempre que se comentan con ocasión de un ataque generalizado o sistemático contra una población civil y con conocimiento de dicho ataque, lo cual 
a las que con conocimiento de causa se refiere el ex representante Motta Motta en su declaración y la Corte Interamericana en la decisión indicada.

Por lo tanto, bien se expresó en la audiencia preparatoria al fijar de manera definitiva los límites de la imputación jurídica, el juicio de adecuación típica y la punibilidad tiene referente en disposiciones del decreto 100 de 1980, pero su valoración trasciende el bien jurídico de la vida e integridad en su consideración individual al incorporar la conducta como hecho social a un sistema de valores vinculado al respeto a los derechos humanos, lo cual también explicó la Sala.

En este sentido, el derecho comparado ha empleado estas alternativas con el objeto de superar decisiones formalmente correctas pero materialmente injustas, acudiendo a fórmulas sustanciales que encuentran en la filosofía de los derechos humanos un principio de valoración material de la antijuridicidad penal. Así, por ejemplo, en el caso contra el ex presidente Alberto Fujimori, la justicia peruana subsumió la conducta en los tipos penales de la legislación ordinaria, pero consideró, al igual como acá se sostiene, que los delitos imputados en atención a sus características trascienden su consideración estrictamente individual y por lo tanto se "adecuan plenamente a lo que internacionalmente y en el momento de su persecución, se califica de crímenes de lesa humanidad." 24

De manera que estas reflexiones no contemplan la conducta y sus implicaciones desde un perfil individual, sino de acuerdo con elaboraciones contemporáneas, las cuales incorporan la filosofía de los derechos humanos como elemento esencial de interpretación de la norma penal y de la antijuridicidad del comportamiento con el fin de superar soluciones formales que pueden conducir a intolerables lagunas de impunidad.

La Sala apreciará, en ese contexto, el comportamiento que se atribuye al doctor CESAR PÉREZ GARCÍA y determinará las conclusiones de acuerdo con ese marco jurídico.

Tercero. La defensa, según se ha señalado, cuestiona el testimonio de Alonso de Jesús Baquero, alias "Vladimir", principal acusador del ex congresista aludido, desde varios puntos de vista, uno de lo cuales consiste en tildarlo de ser un testigo de referencia que solamente después de varias intervenciones ante autoridades de distinto orden vinculó al procesado, en un hecho que el defensor asegura no planeó, ni sugirió que se cometiera.

Pues bien: El proceso penal busca la aproximación racional a la verdad y la correcta aplicación del derecho sustancial dentro del respeto de las garantías

quiere decir que los delitos de lesa humanidad contienen un elemento material (ataque masivo o sistemático contra una población civil) y otro de orden subjetivo (el autor debe tener conocimiento de la existencia del ataque). Cfr, Ramelli Arteaga en el libro citado, páginas 272 a 278.

${ }^{24}$ Corte Suprema de Justicia de Perú, Sala Penal Especial. Exp. No. A.V.19-2001. 
constitucionales. Eso significa que esas finalidades tienen un límite material en la salvaguarda de los derechos de los sujetos procesales, y otro formal en la sana crítica, razón por la cual salvo por la ilegalidad o ilicitud del medio de prueba, de manera que mientras se respeten esos axiomas, no existe tarifa legal alguna que excluya de antemano ningún medio de convicción, según lo dispone el principio de libertad probatoria. ${ }^{25}$

Con todo, la defensa insiste en que el testimonio de Alonso de Jesús Baquero, es de oídas o de referencia, y por lo tanto por virtud de la aplicación favorable del artículo 381 de la ley 906 de 2004, insuficiente para dictar sentencia condenatoria contra su defendido, teniendo en cuenta que esta norma dispone que "la sentencia condenatoria no podrá fundarse exclusivamente en pruebas de referencia."

De una vez se debe advertir que el testimonio del mencionado no se puede apreciar desde la perspectiva que la defensa propone, para adscribirlo a una categoría con el propósito de demandar la absolución del sindicado, pero aún si se aceptase que fuese testigo de referencia, no se podría aplicar la regla negativa cuya aplicación favorable se reclama, pues no se trata de un testigo único y de otra parte no existe afinidad dogmática de instituciones cuya aplicación por favorabilidad se demanda.

En ese sentido, la Sala ha señalado que por virtud del principio de favorabilidad, normas de la ley 906 de 2004 pueden aplicarse a asuntos que se tramitan con base en el sistema de la ley 600 de 2000, a condición de que las instituciones sean afines a los dos sistemas. ${ }^{26}$ Pero eso no significa que bajo esa reflexión, las reglas de apreciación probatoria se puedan considerar una institución común a los dos sistemas, teniendo en cuenta que el método de investigación, de producción de la prueba y el principio de inmediación, son sustancialmente distintos en los sistemas procesales indicados.

En efecto: En el proceso penal de la ley 600 de 2000, la prueba se produce desde la fase de indagación preliminar, y por supuesto a partir del instante en que se declara formalmente abierta la investigación penal, sin necesidad de que se repita en el juicio, pues impera el principio de permanencia de la prueba, a condición de que los sujetos procesales hayan tenido la posibilidad jurídica de controvertirla (artículo 401 de la ley 600 de 2000). ${ }^{27}$ En cambio, en el sistema procesal de la ley 906 de 2004 se realizan "actos de investigación", de manera que por regla general únicamente se considera prueba la que se practica en

\footnotetext{
${ }^{25}$ Al respecto, la Sala ha sostenido que: "el principio de libertad probatoria, de acuerdo con el cual, los elementos constitutivos de la conducta punible y la responsabilidad del procesado, entre otros aspectos, pueden ser demostrados con cualquier medio probatorio, a menos que la ley exija una prueba especial para ello, situación que no es dable predicar para el presente caso." Cfr. auto del 4 de mayo de 2010, radicado 34003.

${ }^{26}$ Radicado 24959 del 16 de marzo de 2006, entre otras.

${ }^{27}$ Segunda Instancia Rad. 36402 del 5 de septiembre de 2011.
} 
el juicio (artículo 374), y por ello es imperativa la cláusula según la cual la "sentencia condenatoria no podrá fundarse exclusivamente en pruebas de referencia."

Esa afirmación tiene razón de ser en el principio de contradicción como condición axiológica de la controversia procesal, debido a que en la ley 600 de 2000 la confrontación es continua, mientras que en la ley 906 de 2004 se concentra en el juicio penal, por principio único escenario en que se materializa la prueba como medio de aproximación racional a la verdad. Por lo mismo, según el artículo 437 de la ley indicada, es prueba de referencia toda declaración realizada por fuera del juicio oral, no tanto por el momento en que se produce, sino por la imposibilidad de controvertirla en la vista verbal, por regla general, fase normal de producción de la prueba, con excepción de lo regulado en torno de la prueba anticipada.

En conclusión, aparte de que no se trata de un testigo único, la epistemología en que se sustenta la aproximación racional a la verdad y el distinto fundamento de los principios de contradicción y de inmediación, impide la aplicación de las normas de la ley 906 de 2004 que la defensa demanda.

Cuarto. Nadie discute, porque es un hecho que no requiere mayores reflexiones, el homicidio de varias personas y las lesiones de otras por parte de escuadrones de la muerte la noche del 11 de noviembre de 1988 en el municipio de Segovia, acontecimiento que por sus efectos simbólicos en el quehacer social y político de esa región y de la nación toda, se constituyó en un episodio de dimensiones superlativas, cuya apreciación desde el punto de vista penal implica superar los umbrales de reflexión que ordinariamente se emplean para analizar conductas de la llamada delincuencia convencional, debido al alto contenido de intolerancia y a la incidencia en la política de preservación de los derechos humanos como imperativo ético de un Estado democrático.

En ese orden, el análisis de la conducta requiere aprehender las circunstancias históricas, políticas y sociales que rodean el comportamiento y apreciar la prueba de acuerdo a como actúan los llamados "escuadrones de la muerte" o "grupos armados por fuera de la ley", con el fin de superar arquetipos convencionales que sin consideración al contexto, pretenden restarle crédito al principal testigo encasillándolo en clasificaciones formales con el fin de cuestionar su credibilidad, muy a pesar de que quien declaró en contra del procesado fue el ejecutor de la "masacre" y no un sujeto extraño que hubiese conocido de ella por lo que le dijeron o le contaron, sino por lo que vivió.

Pues bien: El Municipio de Segovia, recuérdese, hace parte del nordeste antioqueño, una zona convulsionada social y políticamente por la presencia de múltiples grupos armados ilegales de las más diversas tendencias; al punto que, precisamente en 1988, y aún antes, como consecuencia de tantos procesos políticos fallidos, las agudas contradicciones dejaron en evidencia la intemperancia de grupos de ultraderecha frente a partidos que al decir de unos, tenían respaldo de organizaciones subversivas y que en nombre 
de la Unión Patriótica irrumpieron en el escenario político para entonces dominado, según había sido la tradición, por dos partidos proverbiales.

En efecto, Segovia conjuga la historia de caciquismos y de liderazgos locales, compatibles con un orden constitucional excluyente y centenario que limitaba la participación política. Por eso no es extraño que Julio César Restrepo Cadavid con razón ilustre la situación social y el entorno del poder local en los siguientes términos: "...y se fueron volviendo como caciques, entonces allá quedó el señor César Pérez García; allá pues como líder de esa región de allá y a nivel local pues el más cacique era un señor Sigifredo Zapata, que era como decir la mano derecha de ese señor que todo lo que pasaba allá ahí mismo llamaba hablar con él... Si porque el señor Pérez era como decir el cacique político de la región y el señor Sigifredo era como el cacique local, entonces los alcaldes los nombraba la secretaría de gobierno departamental, entonces el tipo se disfrazaba. El era latonero y mecánico, pues el Sigifredo, entonces él se ponía su ropa de trabajo y se paraba en la esquina a ver y si el alcalde no funcionaba como él decía él llamaba a César Pérez y el alcalde ahí mismo lo cambiaban... Eso era un conocimiento general allá en el pueblo..." 28

O, en palabras de Javier Ávila: "Lo que pasa es que él era el jefe político de toda la zona y entonces él ponía los alcaldes, cierto. El gobernador de turno le apoyaba esos alcaldes y eso se veía en casi todos los municipios donde el partido liberal, el partido conservador estaba ahí y se presentaban esos cambios, cierto. Como eran nombrados a dedo, digamos, entonces se presentaban y él era un político o ha sido un político muy importante y entonces él en todo el nordeste tenía casi todos los alcaldes eran de él...."29

En ese escenario político y pese a la estigmatización del grupo como un partido vinculado con organizaciones ilegales de izquierda, la Unión Patriótica logró en la primera elección popular de alcaldes en 1988, elegir a Rita Ivonne Tobón Areiza y a siete de trece concejales, y romper la hegemonía del partido liberal que CÉSAR PÉREZ GARCÍA dirigió por años con inocultables réditos políticos, hecho impensable en el concierto de una práctica que por buen tiempo le había negado a fuerzas distintas a las convencionales la posibilidad de acceder al gobierno local.

Este hecho, trascendental en la vida política de Segovia y en su imaginario colectivo, se convirtió en detonante de la intolerancia y pronto grupos de ultraderecha que desdeñan del pluralismo y de la política como factor de inclusión social, notificaron a nombre del denominado movimiento "Muerte a Revolucionarios del Nordeste", que no habría paz política mientras los "idearios democráticos" estuviesen en peligro por la incursión de nuevas fuerzas políticas que en su criterio tenían afinidad con grupos ilegales de izquierda.

${ }^{28}$ Declaración Julio César Restrepo Cadavid, Cuaderno Original 2, folio 232.

${ }^{29}$ Declaración Javier Ávila, Cuaderno Original 4, folio 215. 
En ese contexto, el panfleto en el cual se hacía alusión a la corriente atrás indicada -Muerte a los Revolucionarios del Nordeste- explícitamente mencionaba al doctor CÉSAR PÉREZ GARCÍA, hecho al cual la defensa le resta importancia porque ese documento también se refería al Presidente de Estados Unidos Ronald Reagan y a otros personajes de igual jerarquía, que en su criterio no le aporta nada sustancial a la investigación.

Si se considera únicamente las referencias a personajes como el Presidente de los Estados Unidos de América, el escrito posiblemente no aportaría mayores elementos de juicio, pero si se mira como expresión de una política antidemocrática, adquiere una consideración especial; tanto que al tiempo con la aparición de ese documento arreciaron los hostigamientos contra la población civil, líderes de la Unión Patriótica ${ }^{30}$ y del partido liberal que apoyaron a esa facción política, lo cual demuestra desde el comienzo que la acción posterior fue eminentemente selectiva. ${ }^{31}$

A esta situación también se refiere la ex alcaldesa Rita Ivonne Tobón Areiza, elegida en nombre de la Unión Patriótica, quien más allá de su vehemente imputación en la audiencia pública contra el procesado, contó las amenazas de todo orden contra la Unión Patriótica, y cómo Sigifredo Zapata, político cercano a la cuerda del procesado, tomó un panfleto en el que se informaba del accionar del grupo "Muerte a Revolucionarios del Nordeste", y lo exhibió proclamando que era el principio de la recuperación de Segovia por parte de su "jefe político". ${ }^{32}$

${ }^{30}$ Prueba del hostigamiento lo constituye el telegrama enviado por Juan de la Cruz Mazo Hernández, Presidente del Concejo Municipal de Segovia, el 1 de noviembre de 1988, diez días antes de la Masacre, al Procurador General de la Nación, en el cual señalaba: "Por segunda vez antes de que el Municipio de Segovia y regiones vecinas se conviertan en zonas como el Urabá y Magdalena Medio, denunciamos atropellos, instigamientos (sic) a alcaldesa, concejales Unión Patriótica, militantes de la UP, Partido Comunista y población civil, por parte de Fuerzas Armadas de Colombia (Ejército) y grupos paramilitares, Muerte a revolucionarios del Nordeste M.R.N, y similares, mediante boletines amenazantes y otros concejales Unión Patriótica, por intermedio Presidencia del Concejo, solicitamos desplazar una Comisión Procuraduría. No permita señor Procurador que por falta de atención a denuncias claras, Segovia sea otra Mejor Esquina del país. Atienda nuestro llamado, aún no es tarde."

${ }^{31}$ Ana Rosa Cadavid Vda. De Restrepo, esposa del dirigente liberal Carlos Enrique Restrepo Cadavid, en su declaración del 15 de noviembre de 1988, para indicar la selectividad con que actuaron los ejecutores de los homicidios, “... entonces ahí mismo tocaron la puerta de Emilio Cano, le dieron dos golpes con las escopetas, entonces un muchachito de esa casa que no se como se llama, oyó que uno de ellos dijo, ahí no es, es en esta y señalaron la casa mía. Entonces ahí mismo nos gritaron de la calle abra la hijueputa puerta...".

32 "... y para referirme al nordeste de Antioquia, nosotros obtuvimos una muy buena votación, siendo los primeros comicios en los que participábamos. El riesgo para el partido liberal se empezó a sentir y ellos nos hicieron sentir su miedo con la creación del MRN y el MRN empezó a amenazar a la población civil en el Parque de Segovia. Aparecieron panfletos que 
De manera que la importancia del volante del movimiento en cuestión y otros de similar contenido, apreciados en el contexto social y político de los años 80 en Segovia, consiste en demostrar los altos niveles de confrontación y la intolerancia que se generó por el triunfo de la Unión Patriótica, a lo cual, por lo visto, no eran ajenos los líderes de los movimientos derrotados, pues no en vano Rita Ivonne Tobón Areiza, la recién elegida alcaldesa de ese lugar, pudo percibir directamente las amenazas contra la población civil. ${ }^{33}$

En efecto: El manifiesto de ese movimiento de ultraderecha y los actos de hostigamiento anteriores, se constituyen en mojones de una política de acoso contra la población civil, auspiciada incluso por agentes estatales que impidieron cualquier posibilidad de legitimación por la desviación de funcionarios que, en lugar de preservar la vida y los espacios democráticos, propiciaron conductas ilícitas bajo equivocadas concepciones de Estado y de Justicia, apoyando a los autores de la masacre, según la judicatura tuvo ocasión de pronunciarse.

En ese sentido, no se puede perder de vista que algunos oficiales del Ejército Nacional facilitaron la ejecución de los nefastos hechos de la noche del 11 de noviembre de 1988, con lo cual la intimidación a quienes optaron por políticas distintas, según lo decía el impreso del Movimiento "Muerte a revolucionarios del Nordeste", no fue una amenaza carente de realidad o una actitud simbólica sin contenido alguno, como la defensa pretende demostrarlo resaltando la alusión que en él se hace a personajes de talla internacional.

Por consiguiente, el manifiesto permite entender - y esa es una faceta de su gran utilidad - el contexto social, histórico y político en que se produce la matanza del 11 de noviembre de 1988 en Segovia y comprender las siempre inexplicables connotaciones de un hecho que surge de personajes que desde la ultraderecha con el apoyo de agentes estatales, no estaban dispuestos a ceder espacios a una organización que, desde su particular punto de vista, tenía afinidades políticas con organizaciones o grupos al margen de la ley.

decían hemos creado el MRN para recuperar esta región, guerrilleros y comunistas HP se tendrán que ir o van a morir..." Declaración de Rita Ivonne Tobón Areiza, agosto 16 de 2010 folio 242 C.O. 2.

33 “... luego después de la primera elección de alcaldes, aparecen otros donde dicen que ellos defienden y están por Humberto, no recuerdo el apellido, que había salido alcalde por Remedios y por el doctor César Pérez García, y para ello contamos con el apoyo de Sigifredo Zapata, baluarte de César Pérez en el nordeste antioqueño. En ese tiempo Sigifredo Zapata cogió un panfleto y decía, "ya ve lo que vamos a hacer" En el Parque de Segovia dijo esto no es más que el principio. Para todo el mundo era claro algo que todo el mundo repitió siempre y que era una certeza: que toda esta orientación venía de César Pérez." Declaración de Rita Ivonne Tobón Areiza, agosto 16 de 2010 folio 242 C.O. 2. 
De manera que la llamada "Masacre de Segovia" - como se ha dado en denominar para la historia semejante vejamen contra la población civil -, sucede en un marco conflictivo, es decir, en medio de un conjunto de circunstancias propiciadas por grupos de paramilitares o escuadrones de la muerte e incluso actores institucionales del más diverso orden. En ese sentido, se ha indicado, la justicia probó la vinculación de orgánicos del Ejército Nacional en la acción de Segovia ${ }^{34}$ y estancias de mercenarios en el Batallón Bomboná, hechos que se constituyen en antecedentes inmediatos de un acuerdo siniestro que Alonso de Jesús Baquero, alias "Vladimir", ejecutó y que pese al pacto de silencio propio de estas organizaciones, años después dio a conocer a la justicia.

En este margen, por la confluencia de actores de todo orden en la ideación, planificación y ejecución del operativo ilegal, se puede concluir que la acción fue realizada por un colectivo criminal que desde la perspectiva dogmática se cataloga como un grupo armado al margen de la ley. Por lo tanto, ninguna duda cabe de que quienes concurrieron a la ejecución de la "masacre" se concertaron previamente y de esa manera incurrieron en la comisión del delito de concierto para delinquir, conducta reprimida con la mayor severidad mediante disposiciones dictadas en ese momento al amparo del "Estado de Sitio", en relación con estructuras de sicarios y organizaciones terroristas, precisamente con el fin de enfrentar graves atentados contra la población civil. ${ }^{35}$

Es decir, el acusado asumió los propósitos que motivaron al grupo ilegal, sobre todo, la persecución que realizaban contra los grupos subversivos, la población que eventualmente los apoyaba y, de manera más concreta, los militantes y partidarios (población civil) de la Unión Patriótica, disidentes de la tradición política impuesta en las regiones por los partidos políticos tradicionales, como es el caso del partido liberal que lideraba César Pérez García en la región de Segovia, de modo que el concierto para delinquir es incuestionable.

\footnotetext{
${ }^{34}$ Alonso de Jesús Baquero, acerca de la vinculación de orgánicos del Ejército Nacional con las autodefensas y la llamada Masacre de Segovia, señaló: "Henry Pérez me dio la orden de hacer la vuelta en Segovia, mejor no me dio la orden sino que dijo que qué pasaba en Segovia que yo no le había metido el diente a esa área, entonces yo le expliqué los motivos que eso estaba muy organizado por la guerrilla y que tocaba con despacio. Entonces me dijo Henry que nada, que la misión mía era hacer en esos días la masacre en Segovia y ahí fue cuando yo me reuní con Navas Rubio.

${ }^{35}$ Entre las razones que se ofrecieron en el decreto 1038 de 1984 para declarar turbado el Orden Público y el Estado de Sitio en todo el territorio nacional de conformidad con el artículo 121 de la Constitución de 1986, se señaló la necesidad de enfrentar actos contra el Orden Constitucional y la Población civil por la operación de grupos armados al margen de la ley. En esa línea, el artículo 7 del decreto 180 de 1988, señaló que el que forme parte de un grupo de sicarios o de una organización terrorista, incurriría por ese solo hecho en una pena de 10 a 15 años de prisión.
} 
En este sentido, como se alcanza a comprender, una de las mayores preocupaciones de ese momento, era enfrentar la acción de grupos armados al margen de la ley, para lo cual precisamente se diseñó una legislación de emergencia por los nefastos efectos de la acción de estas organizaciones contra la seguridad pública, bien jurídico institucional que se concibe en el modelo de Estado democrático como un escenario esencial para garantizar los ámbitos de libertad y el ejercicio de los derechos fundamentales. ${ }^{36}$

En consecuencia, la confluencia de actores de todo orden en la planificación, preparación y ejecución del operativo ilegal, indica que la acción fue realizada por un colectivo ilegal armado con una tradición histórica que por el solo hecho de su conformación puso en riesgo la seguridad pública, y cuyo trasegar en la geografía nacional con la finalidad de atacar grupos sociales y políticos contrarios al ideario de las autodefensas, aumentó el riesgo contra las condiciones mínimas de seguridad indispensables para el ejercicio de derechos fundamentales.

Es más, la consideración que ha hecho la Sala de los acontecimientos ocurridos en el municipio de Segovia como delitos de lesa humanidad, en atención a que este suceso fue consecuencia de un ataque sistemático y generalizado contra la población civil, supone necesariamente un acuerdo de voluntades que permanece en el tiempo y que afecta la seguridad pública, bien jurídico cuyo riesgo se incrementó por la persistencia de las acciones de este grupo ilegal.

De la persistencia del acuerdo y de los nexos entre CÉSAR PÉREZ GARCÍA y éste tipo de grupos ilegales, hablan con propiedad Iván Roberto Duque y Daniel Rendón Herrera, de manera que no se puede decir que PÉREZ GARCÍA participó de un segmento de una acción ejecutada por un colectivo ilegal, sino que fue parte de un acuerdo que perduró en el tiempo y que incrementó, por ese solo hecho, el riesgo contra la seguridad pública como bien jurídico funcional. ${ }^{37}$

36 "El problema que toda cultura, sociedad o Estado debe resolver es trazar los límites, dentro de los cuáles el ser humano puede ejercer esa libertad. Esta delimitación de los márgenes, dentro de los cuales se permite el libre desarrollo de la personalidad y el ejercicio de la libertad por parte de los individuos, se llama 'seguridad'. Esta no es más que la expectativa que podemos razonablemente tener de que no vamos a ser expuestos a peligros o ataques en nuestros bienes jurídicos por parte de otras personas.'

${ }^{37}$ La Corte Suprema de Justicia, en sentencia del 23 de septiembre de 2003, Radicado 19712 señaló: “. . l la conducta punible de concierto para delinquir es un acuerdo de voluntades para cometer delitos indeterminados, el cual para su existencia basta con la comprobación del pacto de asociación delictiva de manera permanente, sin que sea necesario particularizar los medios que se van a emplear. Distinto acontece con la comisión de delitos en concreto, en la que se planifica cómo va a efectuarse cada uno de estos." A su vez, el mismo Alto Tribunal en decisión del 22 de julio de 2009, radicado 27852 puntualizó: “Condición esencial para la configuración de esta especie delictiva es, por tanto, la creación de una asociación 
De otra parte, el contexto en que se produjo la conducta y la manera como se cumplió el plan, demuestran que se trató de una típica operación de grupos armados al margen de la ley que actúan bajo una unidad de mando jerarquizada en la que no existe, la mayoría de las veces, ni siquiera el más leve contacto entre el ejecutor material y quien imparte la orden, aspecto sustancial para apreciar el testimonio de alias "Vladimir", del cual la defensa se vale para catalogarlo como testigo de oídas y de referencia en orden a cuestionar su credibilidad.

De modo que si la llamada "Masacre de Segovia" fue ejecutada por un grupo armado por fuera de la ley, es posible afirmar que no necesariamente tiene que existir una relación directa entre el que ordena, sugiere, manda o imparte la orden, y el que ejecuta la conducta, tema que desde la postguerra ha permitido atribuir responsabilidad a aquel que detenta el poder de impulsar o pausar la acción a su antojo o conveniencia, pese a que no exista contacto directo con el ejecutor material.

En esa medida, la apreciación de la declaración de Alonso de Jesús Baquero con cánones tradicionales que encuentran en la relación directa entre quien imparte la orden y quien la ejecuta, el único fundamento admisible de aproximación racional a la verdad, es insuficiente para juzgar complejas modalidades de criminalidad que no corresponden a estereotipos de la llamada delincuencia convencional, máxime si en este caso, la declaración de alias "Vladimir" encuentra respaldo en la versión de Iván Roberto Duque y Fredy Rendón Herrera, quienes se refieren a los vínculos entre CÉSAR PÉREZ GARCÍA, Fidel Castaño y Henry de Jesús Pérez, gestores también de la masacre, lo cual refuerza la credibilidad de la declaración de aquél.

u organización para violar la ley penal, estructura que presupone, a su vez, la confluencia de varios elementos, (i) un número plural de personas, (ii) un acuerdo de voluntades que convoque a los asociados alrededor de un mismo fin, y (iii) la proyección de la organización en el tiempo con carácter de permanencia." Por su parte, La Corte Constitucional en relación con los elementos constitutivos del delito de concierto para delinquir señaló en la Sentencia C 241 de 1997 lo siguiente: "Cuando se señala como elemento constitutivo esencial del concierto para delinquir, que la societas sceleris pretenda la comisión de "delitos indeterminados", ello no puede interpretarse en el sentido de que el tipo penal se desvirtúa si la organización criminal se especializa en la comisión de un determinado tipo de delitos; la indeterminación que señala la doctrina como esencial para que se configure el delito del concierto, se refiere a la disposición de los sujetos activos del delito, de trascender la mera comisión en un espacio y tiempo determinados, de uno o varios y específicos hechos punibles, caso en el cual se configura la coparticipación, pues el rasgo distintivo del tipo penal que se analiza es el carácter permanente de la organización que se dedica sistemáticamente a las actividades delictivas, la cual opera como una empresa organizada, que como tal se "especializa" en determinadas conductas. 
Es más, si se acepta que quien tiene el dominio sobre la organización, o que él u otro en su nombre puede impartir órdenes vinculantes que desembocan en la ejecución de un delito por parte del autor inmediato que hace parte de una estructura ilegal jerarquizada, es posible comprender que las órdenes del "Estado mayor" se cumplen sin que sea necesaria la comunicación directa entre quien imparte la orden y el ejecutor, o que no necesariamente entre quien determina al jefe de una organización y el autor material debe existir una relación directa e inmediata, lo cual explica que alias "Vladimir" haya recibido órdenes de sus superiores sin tener contacto con el determinador de la conducta. Además, es bueno destacar otros aspectos referidos al testimonio que rindiera Alonso de Jesús Baquero, con miras a establecer que su dicho coincide con varios de los episodios narrados por otros declarantes, lo cual permite predicar del mismo que, según se viene afirmando, no es insular según lo sugiere la defensa, y de otro lado, que existen hechos y circunstancias que fueron escuchadas en el proceso mucho antes que "Vladimir" rindiera su versión y en las que se mencionan aspectos que vinculan al político liberal, lo cual permite darle soporte y una mayor envergadura a las atestaciones que ofreciera Baquero. Por ello resulta claro que la Sala, como ya se anunciara, le otorgue pleno crédito a sus afirmaciones porque no surgen de la fantasía del deponente sino que encuentran apoyo en episodios narrados por otros actores del proceso.

En efecto: Uno de los más recurrentes argumentos de la defensa para desestimar las afirmaciones de Alonso de Jesús Baquero es que su testimonio es producto de la ficción y que toda la investigación se soporta o nace en contra de CÉSAR PÉREZ GARCÍA, una vez se rinde el testimonio amañado de este testigo; en ese entendido se afirmó "que todo empieza y termina con el testimonio de Vladimir", lo cual no es fundado.

Veamos: concurren testimonios de diferentes personas que confluyen a demostrar la responsabilidad del procesado en los hechos que dejan sin sustento las tesis defensivas esgrimidas, ya que en la construcción de las mismas se obviaron, convenientemente, algunas de estas versiones que permiten dar un giro a la investigación para afianzar el compromiso del procesado en los hechos.

Por ello, la vinculación del político con el episodio delictivo no surge exclusivamente de la declaración de "Vladimir"; no todo comienza y termina con él, porque mucho antes ya se escuchaba el nombre de CÉSAR PÉREZ GARCÍA en calidad de gestor de los hechos.

Resulta de vital importancia esta situación en el entendido que lo construido en el expediente no surge a partir del "veleidoso declarante", según lo refiere la defensa en conjunto, sino que sus manifestaciones son una parte del recaudo probatorio que se encuentra en el proceso y que permite, al construir un análisis armónico, determinar no sólo los artífices de la comisión sino a quienes actuaron en la sombra para acordar la realización de estos hechos, 
amparándose como el acá investigado, en su prestancia, que para la época ostentaba en el concierto local, departamental y aún nacional.

De otra parte, la crítica testimonial señala que en principio es más veraz la declaración de quien percibe directamente los hechos que el testimonio de aquel que obtiene el conocimiento indirectamente. Pero eso no significa, aún de aceptar que el testimonio de Alonso de Jesús Baquero fuese único y de referencia, cuestión que por supuesto es de muy dudosa recepción, que se deba desestimar, pues no existe ninguna tarifa legal o regla científica o de experiencia que así lo imponga y de allí que su apreciación quede al cabal juicio de la sana crítica (artículo 282 de la ley 600 de 2000).

La defensa reitera a lo largo de su exposición que el testimonio de Alonso de Jesús Baquero, alias "Vladimir", es tardío, interesado, único y de referencia, características que en su criterio desdicen de su credibilidad. Tardío porque fue después de muchos años que decidió vincular a CÉSAR PÉREZ GARCÍA con la "Masacre de Segovia"; interesado pues lo hizo con el afán de obtener beneficios judiciales; único toda vez que aparte de él nadie con conocimiento de causa sabe de la participación del acusado en semejantes hechos, de manera que "todo comienza y termina en sus decires"; y de oídas, en cuanto que el testigo lo que narra lo hace porque otros al parecer le dijeron que el acusado propició el operativo.

Es cierto que Alonso de Jesús Baquero no mencionó en sus primeras intervenciones al citado ni a otros e inclusive no aceptó que hubiese dirigido la acción delincuencial, pese a que habitantes de Segovia lo señalaron como el jefe de la cuadrilla de paramilitares que sembró el pánico y la muerte el 11 de noviembre de 1988. Solamente ante la identificación de varias personas que lo distinguían con el alias de "Alfredo", según se le conocía en las filas de la guerrilla, facción a la cual perteneció antes de involucrarse con otros grupos sin la menor afinidad ideológica, confesó siete años después su participación.

De manera que por no haber aceptado su participación desde la primera vez cuando concurrió ante la Procuraduría General de la Nación o no delatar a los principales artífices de la "masacre", su confesión no merece credibilidad. Al contrario, la regla de la experiencia indica que no siempre quien ha cometido un delito lo acepta ante la justicia. Es más, generalmente se admite que ante la carga que tiene el Estado de demostrar la responsabilidad, quien está comprometido en un hecho delictual usualmente niega su vinculación con los actos que se le imputan. En ese sentido, la admisión tardía de responsabilidad de "Vladimir" es explicable y ello en sí mismo no afecta su credibilidad ni su contenido.

Tampoco es esencial para descartar la veracidad del testigo su interés por obtener beneficios legales, pues aún cuando alias "Vladimir" hubiese admitido su responsabilidad y la intervención de otros con fines utilitaristas, ese propósito no permite desestimar de antemano su aptitud probatoria, 
aun cuando esa "singularidad", que es como el artículo 277 de la ley 600 se refiere a esas circunstancias, obliga a emplear mayor agudeza y reflexión en procura de establecer el mérito y la credibilidad del declarante.

$\mathrm{Al}$ respecto la Sala ha sostenido:

“...Por tanto, sin dificultad se colige que no todo aquél que concurre a suministrar información sobre la comisión de delitos es necesariamente veraz o ineludiblemente embustero, pues en cada caso concreto corresponderá establecer, con independencia de que la recompensa se entregue o no, si lo expuesto encuentra soporte en el mundo exterior. (...). No se aviene con el estado actual de la situación del país y con las peculiaridades de delitos como los que motivaron este diligenciamiento, restar mérito suasorio a quienes informan a las autoridades datos exactos y verificados, por el solo hecho de que se les haya prometido la entrega de recompensas económicas o beneficios punitivos, o dicho de otra manera, no es la ausencia del provecho lo que dota de credibilidad a los testimonios, sino la constatación de que lo expuesto encuentra soporte en otros medios de prueba." ${ }^{\prime 38}$

“...Ahora bien: la tesis de ilegalidad del medio de convicción la intentó el defensor desde la tesis insostenible de que provenía de un "reinsertado" que buscaba conseguir beneficios. Una circunstancia así no torna inválida la prueba como tampoco la retractación. Son aspectos a tener en cuenta al apreciar el funcionario judicial la evidencia, cuya descalificación categórica hecha por el censor, opuesta a la conclusión expresada en el fallo, no demuestra la configuración de ningún error trascendente del juzgador. ...(1) Así lo sostuvo la Corte en el auto de casación del 14 de febrero de 2006 (radicación 23.639) y se recordó en el del 14 de septiembre de 2009 (radicación 32.126)..."39

“...4. En primer lugar, la premisa planteada por el censor carece de las notas características de generalidad y universalidad, consustanciales a las reglas de la experiencia, pues no puede afirmarse, como lo hace el demandante, que siempre que alguien declara condicionado a la obtención de beneficios por colaboración, mentirá en su testimonio..."

Ahora: Está probado en el expediente que en torno a lo expresado por Alonso de Jesús Baquero ha girado buena parte de lo que se ha dado en llamar la "línea lógica de investigación", debido a que es él quien, no solo en este proceso, sino en otros, ha dado a conocer los elementos necesarios para hacer un juicio político y jurídico de la llamada "Masacre de Segovia", comprender sus implicaciones históricas, el compromiso de agentes del Estado, sus nexos perversos con organizaciones armadas al margen de la ley y el grado de participación de los principales artífices del operativo demencial, confirmando lo que los habitantes de Segovia sabían y los líderes locales conocían. Por consiguiente y según se dijo en la acusación,

\footnotetext{
${ }^{38}$ Corte Suprema de Justicia, Sala de Casación Penal, Casación 19-02-2009, Rad. 31077.

${ }^{39}$ Corte Suprema de Justicia, Sala Penal, Casación 17-06-2010, Rad. 33734.

${ }^{40}$ Corte Suprema de Justicia, Sala Casación Penal, Casación 24-02-2010, Rad. 31946.
} 
no puede desestimarse en este caso si fue trascendente para determinar la responsabilidad de otros en procesos diferentes.

Con todo, en orden a demeritar la credibilidad del testigo, la defensa considera inexplicable que muchos años después de la "masacre", Alonso de Jesús Baquero, o "Vladimir" se refiriera a CÉSAR PÉREZ GARCÍA, no porque supiera de su real participación, sino porque en su decir, fue informado por Henry Pérez, del interés que tenía en restaurar su poder político en Segovia, algo que para el defensor no es admisible.

Como se ha explicado, la declaración de Alonso de Jesús Baquero no se puede apreciar con reglas convencionales ni menos catalogarla prueba de referencia. Si se admite que es testigo de oídas quien conoce de los hechos que se investigan porque alguien le comentó lo que ocurrió, la declaración de Alonso de Jesús Baquero no se puede adscribir a esa categoría, entre otras razones porque él no fue cualquier actor, sino el ejecutor del operativo criminal, quien precisamente por esa condición debía conocer todos los pormenores de la acción y quienes eran los gestores de la misma, según se lo hizo saber Henry de Jesús Pérez exhibiéndole una grabación entre los principales actores, incluido por supuesto CÉSAR PÉREZ GARCÍA.

En este punto debe resaltarse que la esposa de Henry Pérez, Luz Marina Ruiz Gómez, en la audiencia pública dio fe de la costumbre que tenía el jefe paramilitar de grabar a sus contertulios, agregándose que no es extraño que este le hubiera dado a conocer al testigo esa grabación dada la confianza que rodeaba el trato entre los dos.

En eso, Alonso de Jesús Baquero ha sido consecuente desde el momento en que decidió contarle a la justicia las razones de la masacre, la manera como se planificó el operativo, el apoyo de algunos miembros del ejército y la policía, la identidad de los gestores de la matanza y los móviles de la misma. Así se lo dijo a Ricardo Téllez Gómez ${ }^{41}$, investigador de la Fiscalía, cuando le recibió una entrevista con el fin de valorar su colaboración en el descubrimiento de múltiples delitos de dimensiones superlativas.

Asimismo, ante las autoridades judiciales, Baquero señaló a Henry Pérez y Fidel Castaño, líderes de los ejércitos del paramilitarismo, de haber discutido con CÉSAR PÉREZ GARCÍA el operativo que finalmente se ejecutó, lo cual expuso en la ampliación de indagatoria del 29 de noviembre de 1995,

${ }^{41}$ En lo sustancial, Ricardo Téllez Gómez manifestó: "lo que señalaba Baquero ya en el aspecto eminentemente práctico... que esa orden se la impartían desde Medellín y que era financiada por Rodríguez Gacha y que había políticos de Antioquia y de Santander, y mencionaba a Pérez García a César Përez, que decía que era quien había cuadrado el asunto... "Pero de César Pérez me decía que era él que había hablado con gente de Medellín y con el mexicano que era el que financiaba toda la operación, que había hablado con él y con los Pérez, creo que con Henry Pérez, mencionaba, para hacer lo de Segovia, para limpiar a Segovia y otros municipios de la UP." Declaración noviembre 4 de 2010, folio 221 C.O. 4. 
lo reafirmó en la declaración del 10 de enero de 1996, y lo confirmó en la diligencia de indagatoria del 29 de febrero de 1996.

En esta última diligencia expresó: "Hay un Senador o Representante a la Cámara, no recuerdo que era para ese entonces, en esa época perdió las elecciones en Segovia y su nombre es César Pérez García, a raíz de eso él fue y buscó a Fidel Castaño para que lo ayudara a sacar la UP de Segovia. Fidel Castaño lo contrató, corrijo, lo contactó con Henry Pérez, que en ese tiempo era uno de los jefes paramilitares en Puerto Boyacá. Henry Pérez se reunió con los dos en Medellín, con Fidel Castaño, César Pérez y Henry Pérez. Después de eso Henry me citó a la reunión en Puerto Boyacá. Henry me comentó todo, lo comentado, lo ocurrido en la reunión y me preguntó si conocía a un señor César Pérez, yo le dije que no, pero que sabía que era un jefe político del partido liberal en Segovia. Entonces César me colocó un caset en donde yo escuché la voz de César Pérez donde les pedía ayuda para sacar la UP y a la guerrilla de Segovia. Entonces Fidel Castaño le decía que tranquilo, que eso ya estaba en manos del jefe, refiriéndose a Henry Pérez, y el señor Pérez le decía que le colaboraba con lo que fuera necesario pero que él no podía perder esa región, en Segovia."

También delató a los miembros del Ejército Nacional que facilitaron el operativo y fue fundamental para su condena. Pero ese que sería un valor agregado, la defensa lo acepta con la advertencia de que allí fue testigo directo y no indirecto, como lo es en el caso contra su defendido. En ese sentido, la defensa bajo una óptica lineal que aísla la declaración del contexto, sostiene que la declaración no es suficiente para llevar al juez a la certeza del convencimiento. Pero si se analiza el testimonio en sistemática la conclusión es distinta, como se puede observar al apreciar los nexos de todo orden entre CÉSAR PÉREZ GARCÍA y el paramilitarismo.

Al respecto, Henry Pérez y Fidel Castaño fueron, como se ha demostrado en el proceso, jefes de jefes de los ejércitos paramilitares. Por lo mismo, de acuerdo con la regla de la experiencia, solamente podían tener acceso a ellos personas de indiscutida confianza. Desde luego, porque los líderes de grupos armados al margen de la ley se desenvuelven en círculos cerrados para garantizar su seguridad. Eso explica, que Iván Roberto Duque se haya entrevistado con Henry Pérez, pues éste al igual que aquel compartía los mismos escenarios y propósitos. Y si así es, por la misma razón se tiene que concluir que CÉSAR PÉREZ GARCÍA también lo hizo en esos escenarios de ilegalidad, como lo asegura Iván Roberto Duque, si es que de recurrir a testigos directos se trata.

Precisamente acerca de estos encuentros, entre la ilegalidad y clandestinidad, Duque señaló en su declaración: “...alguna vez, fui a Puerto Berrio... estando allá me invitaron a un almuerzo en una finca, yo no sé si existe actualmente, de pronto sí, se llama Sebastopol, me llamó mucho la atención porque me dijeron que en ese almuerzo va a estar don Henry Pérez, no sabía yo, señora magistrada, que está en Puerto Berrio, que la finca queda relativamente cerca de Berrio, quiero 
recalcar que en muchos encuentros que yo tenía con Henry desconocía a mucha gente que lo visitaban, sin embargo pues para ser concreto para los efectos que persigue esta investigación señora Magistrada, yo fui a la finca Sebastopol, allá me encontré con Henry, sus escoltas..."

Y precisó: , [no audible] ... un Mayor, no recuerdo Señora Magistrada cómo se llama, se identificaba como Mayor de la decimocuarta brigada, dicho sea de paso que Henry tenía muy buenos contactos con las autoridades, las autodefensas todas, y allá habia un político, me lo presentaron, nunca lo había visto en mi vida, me dijo se llama César Pérez García. Me lo presentó directamente Henry Pérez. Almorzamos en esa finca, fue un encuentro primero inesperado; además absolutamente informal. Se conversó de política, yo incluso estuve hablando porque yo todavía era secretario de ACDEGAM, la filiación mía ha sido al partido liberal, entonces me pareció muy interesante haber conocido este señor allá. Yo no lo conocía, en lo personal quiero referirme a eso, pero allá se mencionaba en esa época, distinto ahora, se mencionaba mucho acerca de dirigencia en Antioquia, era un Congresista, recuerdo que hablamos mucho de una cosa que en esa época estaba muy en boga que era la consulta popular..."

Esta referencia es esencial para apreciar el testimonio de Alonso de Jesús Baquero, pues Iván Roberto Duque, alias "Ernesto Báez" confirma los nexos entre Henry Pérez y CÉSAR PÉREZ GARCÍA, que no habrían tenido porqué suceder en circunstancias normales por los vínculos ilegales del primero y la institucionalidad que representaba el otro. Por lo tanto, no se puede sostener que la declaración de Alonso de Jesús Baquero sea insular en orden a probar los nexos entre el político y el jefe paramilitar. Al contrario, por esas razones es admisible que, como lo ha señalado alias "Vladimir", la "Masacre de Segovia" fue sugerida por CÉSAR PÉREZ GARCÍA, quien mantenía vínculos con paramilitares y concretamente con quien le impartió a aquel la orden de ejecutar ese repudiado acontecimiento.

En tal virtud, se aprecia que la declaración de Alonso de Jesús Baquero no contiene verdades aisladas, pues lo que una visión en conjunto de la prueba indica es que su versión la confirman otros medios de prueba que realzan su credibilidad en orden a demostrar la responsabilidad de los principales actores de la matanza. En ese sentido, así como Alonso de Jesús Baquero delató la participación de varios oficiales del ejército en la ejecución del crimen colectivo, cuestión que por lo demás la defensa acepta, también la unidad y universalidad del testimonio de Baquero permite asegurar que CÉSAR PÉREZ GARCÍA fue el gestor de esa causa criminal, por el respaldo que encuentra en declaraciones que demuestran los vínculos entre el político y las organizaciones al margen de la ley.

Por todo ello, el testimonio de este individuo no es una prueba autárquica de la que se pueda decir que deambula sola por el expediente. Por el contrario, su declaración se constituye en el núcleo de una imputación que se reafirma, según se ha visto, desde diferentes perspectivas. En ese 
aspecto, no solo Iván Roberto Duque confirma las relaciones que mantenía el acusado con Henry Pérez. Fredy Rendón Herrera, alias el "Alemán", reconocido paramilitar también manifestó que recibió órdenes de sus mandos en el sentido de pausar las acciones en aquellos sitios, lugares y negocios en los que CÉSAR PÉREZ GARCÍA tenía interés y asociaciones ilícitas. De manera que las andanzas con grupos de ultraderecha no son una mención que se concentre en la versión de alias "Vladimir" sino que son lugar común en el proceso. ${ }^{42}$

De manera que el testimonio de alias "Vladimir", en el sentido de atribuirle a CÉSAR PÉREZ GARCÍA responsabilidades concretas en la ejecución de la "masacre" no es exótico, ni es la manifestación de un interés solapado producto de la invención de quien busca beneficios judiciales, debido a que lo que expresó Alonso de Jesús Baquero en torno a la relación entre CÉSAR PÉREZ GARCÍA y Henry de Jesús Pérez, aun así él no haya percibido ese hecho, es un tema suficientemente corroborado en el expediente, con lo cual la afirmación de que se trata de un testimonio interesado, único y de oídas queda francamente en entredicho.

En síntesis, la probada relación entre CÉSAR PÉREZ GARCÍA y jefes del paramilitarismo de la talla de Henry de Jesús Pérez, líder de las Autodefensas del Magdalena Medio, le confiere credibilidad a la declaración de Alonso de Jesús de Baquero y permite inferir que si entre el político y ese grupo armado existía ese tipo de vínculos, entonces no es apresurado sostener, justamente por esas relaciones confirmadas, que CÉSAR PÉREZ GARCÍA hubiese determinado a Henry de Jesús Pérez a impartir la orden de ejecutar una acción con nefastos efectos en los procesos de construcción democrática.

Pero desde luego que no es solamente la manifestación de alias "Vladimir" la que propicia esas conclusiones, sino un entramado de hechos que a manera de indicios demuestran la participación de CÉSAR PÉREZ GARCÍA en la comisión de la conducta por la cual se le juzga.

Aparte de su indiscutible relación con grupos ilegales de autodefensas, es un aspecto probado que CÉSAR PÉREZ GARCİA fue el más afectado con el ascenso de la Unión Patriótica, como quiera que siempre mantuvo el poder local en modelos estatales en donde las autoridades locales no se elegían sino que se designaban. Este suceso, reconocido por voces de las tendencias más disímiles explica por qué Alonso de Jesús Baquero sí fue enterado por Henry de Jesús Pérez del interés de aquel para que se llevara a cabo la acción militar, mostrándole como evidencia una grabación en la que no quedaba duda para el ejecutor principal, de la participación del político en el proceso de ideación y ejecución de la misma.

Si según se indicó, por la manera como operan los "aparatos organizados de poder" la experiencia indica que entre el operador material y quien imparte

${ }^{42}$ Cuaderno original 1, folio 222. 
la orden no existe relación alguna, eso explica la razón por la cual entre CÉSAR PÉREZ GARCÍA y Alonso de Jesús Baquero no existió ningún tipo de contacto; pero para la cadena de mando sí era indispensable que Baquero Agudelo, el lugarteniente más avezado de la estructura criminal de Henry de Jesús Pérez, contase con toda la información que le permitiera garantizar el éxito de la acción, y de allí la necesidad de que se le hubiese explicado los motivos y quienes eran los interesados en el operativo.

Ahora, en esta serie de acontecimientos siempre se encuentra en la mención del procesado un hilo conductor. En efecto, desde cuando el Movimiento Muerte a revolucionarios del Norte hizo su aparición en "sociedad", se mencionaba al político y se destacaba su liderazgo en la región. Años después, los integrantes del Movimiento Paramilitar Ernesto Báez y Fredy Rendón Herrera reconocían ante la justicia los nexos entre PÉREZ GARCÍA, Henry de Jesús Pérez y Fidel Castaño, mandos de ejércitos de autodefensas.

Por último, aun cuando dice no haber aceptado la sugerencia, Fidel Castaño mencionó el interés de PÉREZ GARCÍA en llevar la confrontación militar a Antioquia con el fin de enfrentar organizaciones insurgentes, lo cual no deja duda de la relación del político con los grupos de ultraderecha y concretamente con el jefe de los aparatos paramilitares, como lo escribió Alejandro Reyes Posada en reportajes conocidos tras la desaparición del líder paramilitar. ${ }^{43}$

Estas referencias confirman que la alusión que hace Alonso de Jesús Baquero en todos los momentos no es el producto de una acusación infundada, pues así como en las primeras ocasiones en las que se mencionó a PÉREZ GARCÍA, en la vista pública Baquero Agudelo se refirió a esos nexos en los siguientes términos: "Después de la masacre nosotros tuvimos una reunión con Fidel Castaño, con el Coronel Navas, en Sebastopol, y Henry de Jesús Pérez; y Fidel Castaño lleva allí un mensaje de agradecimiento de César Pérez... nos decía, bueno de parte de César Pérez muy agradecido, muy contento, todos estamos muy felices, así es que se trabaja Vladimir, mire que si se puede hacer las cosas...".

Esta exposición indica categóricamente que Alonso de Jesús Baquero supo de la participación de CÉSAR PÉREZ no únicamente por las explicaciones de Henry de Jesús Pérez, sino también por la concreta felicitación que recibió a través de Fidel Castaño, situación tanto más admisible si se considera que Fredy Rendón Herrera se refirió precisamente a las relaciones de vieja data entre el Clan de los Castaño y el procesado, hecho que por lo demás también se infiere de la entrevista que Fidel Castaño le entregó a Alejandro

\footnotetext{
${ }^{43}$ Alejandro Reyes Posada, quien entrevistó a Fidel Castaño, condensó que éste manifestó lo siguiente: "Cuando la mafia quiso atacar la guerrilla lo hizo sin una política ni una alternativa económica para la gente. Dijeron que tenía que limpiar a Antioquia para poder vivir bueno. César Pérez García me pidió que llevara mi guerra contra las guerrillas a Antioquia, cosa a la cual me negué."
} 
Reyes Posada, en la cual se alude al interés que tenía el enjuiciado de llevar la guerra a Antioquia.

Por supuesto, esa manifestación del acusado, divulgada por un interlocutor válido como Fidel Castaño, porque a él había acudido justamente para convenir la ejecución de los hechos, de suerte que a ningún otro iba a buscar para hacerlo destinatario de su beneplácito, en conjunto con lo atrás expuesto se erige en elemento incriminatorio en contra del enjuiciado. No es sensato pensar que alguien exprese complacencia por algo, o manifieste un agradecimiento, si no tenía interés. Por consiguiente, esas aseveraciones ulteriores a los hechos, no sacan avante la inocencia de PÉREZ GARCÍA, por el contrario, coadyuvan a consolidar lo que se viene diciendo acerca de su responsabilidad.

En este punto igualmente debe destacarse lo aseverado por Iván Roberto Duque Escobar, alias "Ernesto Báez" en relación con lo dicho por Henry Pérez al acusado en una reunión, lo cual es del siguiente tenor: "...lo que sí tengo perfectamente claro en la memoria, es que estando allá se iniciaron las noticias, se inició el noticiero, en ese noticiero mencionaron la masacre de Segovia, como que la investigación no sé, y con claridad absoluta mencionaron el nombre del doctor CÉSAR PÉREZ, cómo lo mencionaron no recuerdo, si fue una versión del periodista, o si estaban hablando, porque el televisor estaba en la salita, cuando el noticiero inicia HENRY vuela, yo me quedé con Gustavo, mencionan eso, y HENRY después de que mencionan ese nombre, se dirige a las personas que yo no había reconocido ahí en la sala, y le dice doctor CÉSAR está muy caliente, ahí es cuando me doy cuenta que ahí en ese grupo de personas estaba el doctor CÉSAR, cuantas personas eran dos o tres personas, quienes no supe quienes, debo pensar que eran acompañantes del doctor CÉSAR. está muy caliente, fue la expresión que yo escuché de HENRY PÉREZ, que escuché yo, y los que estábamos ahí, que se paró, es decir, esa noticia la dieron algo así como en el marco de la noticia, después Henry se sentó, y así en tono como dijo está bien preocupado..." 44

Lo dicho por Henry Pérez al acusado en el sentido que estaba caliente, no admite interpretación diferente a su compromiso con los hechos de Segovia, más aún si según lo expresara el deponente aludido, ello acaeció inmediatamente después de emitirse una noticia relacionada con el insuceso. Por consiguiente, si nada hubiera tenido que ver aquél no es lógico lo dicho por Henry Pérez, de manera que la exclamación referida proveniente de quien estaba relacionado con el comportamiento punible, se erige en un elemento indirecto de apreciable fuerza incriminatoria en contra del acusado.

Quinto. De otra parte, la "Masacre de Segovia" se ha descrito como un acto de retaliación política contra la Unión Patriótica, conclusión que se pretende minimizar con el argumento de que algunos de los muertos pertenecían al

${ }^{44}$ Declaración IVÁN ROBERTO DUQUE, folio 179 C.O. 1. 
partido liberal y que por tanto el acusado, desde ese punto de vista, no podía estar interesado en ejecutar ese crimen.

Al respecto, la consideración política e histórica del hecho permite aseverar que los beneficiados estaban vinculados con la política local, debido a que los réditos del crimen favorecían a un sector tradicional con fuerte influencia en esa región, y de otra, que la acción se dirigía contra la Unión Patriótica, movimiento al cual habían adherido antiguos militantes del partido liberal por el incumplimiento proverbial de las fuerzas tradicionales a sus aspiraciones.

Por eso la circunstancia de que algunos de los muertos fueran liberales o que apoyaron en otras épocas a PÉREZ GARCÍA, no incide en las conclusiones que prohíja la Sala, puesto que ante el fracaso de los partidos con fuerte acento en acciones políticas clientelistas, los segovianos optaron por una alternativa diferente en la primera elección popular de alcaldes. Así, Hernán Darío Londoño Hernández, sostuvo: "Nosotros acá como liberales de tradición siempre hemos apoyado las listas que encabeza César Pérez García, entonces como aquí había mayoría liberal y nosotros liberales queríamos que el municipio le diera una casa a Arminda, entonces las casas las repartieron y a la señora no le dieron casa, entonces por esa razón todos nosotros nos resentimos y no quisimos acompañar al Directorio Liberal y seguramente con esa negativa del voto liberal firmamos la sentencia de muerte..." 45

De igual modo, Julio César Restrepo Cadavid, ya citado en esta providencia, hizo alusión a César Pérez García y a Sigifredo Zapata, al primero tildándolo de "cacique político" de la región y al segundo de carácter local y "mano derecha" del acusado; hizo énfasis para formular los asertos, en que prácticamente todos los nombramientos se hacían con el visto bueno de aquel.

De modo que de las declaraciones de Hernán Darío Londoño Hernández y Julio César Restrepo Cadavid, se puede inferir, primero, que la acción de Segovia fue contra la población en general y contra la Unión Patriótica en particular, y segundo, que, CÉSAR PÉREZ GARCÍA, era el "Cacique de Segovia" y en esa condición dispuso a su antojo del poder que un modelo de democracia absolutamente imperfecta le permitía, por lo cual si alguien resultaba perjudicado con los resultados electorales que abrían espacio a un nuevo mapa político, era el acusado.

En cuanto a lo primero, es evidente que se trató de una acción selectiva, planificada y desarrollada contra una población y por motivos específicos. En este sentido, el Brigadier General Carlos Arturo Casadiego Torrado, Director Operativo de la Policía Nacional, señaló con su reconocida autoridad y experiencia: "La acción de los delincuentes fue planeada detenidamente y en detalle. Indiscriminadamente actuaron en contra de personas

${ }^{45}$ Declaración folio 22, anexo 8. 
que se encontraban en lugares públicos pero predeterminados por estos, como son los bares Johnny Kay, el Amañadero y el Kiosco del Parque Central. Selectiva contra algunas personas que se encontraban en su residencia. Los victimarios son personas que conocían perfectamente la ciudad, a las víctimas y establecimientos públicos que seleccionaron. En los lugares públicos dispararon indiscriminadamente fusiles $R 15$ y granadas de fragmentación. Penetraron en alguna casa en donde indagaron por personas habiéndose dado muerte en el acto." 46

Estas conclusiones corresponden a una verificación empírica, pues el Brigadier corroboró "in situ" que al Bar Johnny Kay, escenario singular de la acción, concurrían afectos a la Unión Patriótica. Las calles Reyna y la Madre eran igualmente un sitio de residencia de militantes de ese partido, y además un lugar señalado por organismos Estatales como centro de operación de la guerrilla.

También las casas de personas previamente seleccionadas, como la de la familia Restrepo Cadavid, con lo cual se demuestra definitivamente que fue una acción contra un grupo de personas unidas por afinidades políticas distintas a la que era en ese entonces la "oficial".

En cuanto a lo segundo, la reivindicación del político en el panfleto del "Movimiento Muerte a Revolucionarios del Norte", explica la importancia de CÉSAR PÉREZ GARCÍA para este movimiento de ultraderecha, interesado en la defensa de la manera como se construían las relaciones de poder entre la autoridad y el ciudadano en esa región del país. Por eso no es exótico que ese grupo hubiera reivindicado al caudillo, anunciado la restauración del orden en el municipio y su interés de recuperar para la "institucionalidad" el poder local, situación en la cual también estaban interesados los jefes municipales de los partidos tradicionales.

Bien diciente resulta esta comunicación y no se puede aceptar, dado lo ya expresado, el argumento defensivo cuando pretende que el contenido de la misma resulta ajeno al ex parlamentario, como quiera que lo allí afirmado hace expresa alusión a los quereres del político cuando se reunió con Henry Pérez y Fidel Castaño para solicitar se ejecutara la incursión armada.

Este comunicado se erige en la referencia anticipada de lo que en Segovia iría a ocurrir "...Saldremos con un gran golpe mortal..." y a fe que ello se concretó. No fue entonces una simple insinuación o velada amenaza, sino que se materializó con la orden impartida a alias "Vladimir", para que llevara a término la acción delictiva en la cual sin duda tenía especial interés CÉSAR PÉREZ.

Aparece bien coincidente que aquella petición de PÉREZ GARCÍA, para sacar a la Unión Patriótica de Segovia, concuerde con los términos del escrito antes aludido; ello necesariamente refleja que efectivamente el acercamiento

${ }^{46}$ Informe 5063 noviembre 17 de 1988, folio 218, anexo 13. 
entre el dirigente liberal y los paramilitares no sólo era verdadero sino que esa relación de amistad permitió que sus peticiones fueran escuchadas y aún plasmadas en escritos intimidatorios que llegaron a la población.

En tal virtud, lo expresado en el comunicado acerca del apoyo al procesado no puede entenderse producto de la casualidad, sino otorgado deliberadamente a una persona que compartía propósitos y sentimientos, por todo cuanto había acaecido en el panorama político regional.

Desde luego, debe afirmarse que la alusión en el comunicado referido a Sigifredo Zapata, estrechamente vinculado políticamente con el acusado, refuerza lo aducido en cuanto a que nada de lo que allí se menciona fue casual, y por el contrario, se vislumbra la relación de éste con ese movimiento, de modo que la opinión en contrario de la defensa no persuade.

En este orden, la declaración de Alonso de Jesús Baquero permitió traer al proceso lo que en Segovia era una verdad sabida. Edison Gildardo Silva Sierra y Omar Hernando Pérez, dos políticos regionales, señalaron que si algo estremeció a la población fue la pérdida de tantas vidas indefensas mediante una acción que atribuyeron al imputado. Tenían razones: el más significativo perdedor por su ancestro político fue CÉSAR PÉREZ GARCIA, y el paramilitarismo como defensor de una institucionalidad excluyente. Por eso es perfectamente admisible que la versión de los ciudadanos sea compatible con la de Alonso de Jesús Baquero. Dicho de otro modo, éste confirmó para la justicia y para la historia algo que para la gente de Segovia era un axioma: que el aludido era responsable de la "Masacre de su pueblo".

Por supuesto que la Corte entiende que no es el comentario generalizado o el rumor el que permite asumir que fue el enjuiciado el autor de la orden de exterminio contra la población civil, sino que esa voz popular fue confirmada con la declaración de alias "Vladimir" y con la de importantes jefes paramilitares que declararon acerca de los vínculos del político acusado con esos grupos de autodefensa. En otras palabras, es la prueba legalmente producida la que demuestra lo que la población de Segovia conocía, de tal modo que existe coincidencia entre el juicio jurídico y el de la opinión.

Ahora, que en principio la ciudadanía no hubiese hecho referencia a los autores ni hubiera realizado juicios de responsabilidad es explicable. Recién acaecida la masacre, el ex-defensor del Pueblo, Jaime Córdoba Triviño, pudo percibir un estado de temor generalizado y una situación en donde, según sus propias palabras, "se presuponía que los miembros del ejército, de la policía, estaban involucrados de alguna manera."

Apreciación en la cual coincide la ex alcaldesa Rita Ivonne Areiza, quien aseveró que inicialmente concurrieron a declarar con miedo porque era evidente que la orden de recuperar el municipio se había cumplido y por lo tanto no tenían garantías para declarar ante los jueces. 
Tiempo después, superada esa circunstancia, en el discurso que pronunció el 27 de octubre de 1989 el diputado Gabriel Jaime Santamaría Montoya mucho antes de que Alonso de Jesús Baquero declarara ante la justicia -, le atribuyó a CÉSAR PÉREZ GARCÍA haber sido partícipe de la masacre, según lo declaró Guillermo Gaviria Zapata, fórmula política del procesado 47, con lo cual el juicio político, el de opinión y el jurídico confluyen en una misma conclusión.

En fin, no es la manifestación de Alonso de Jesús Baquero únicamente la que incrimina a CÉSAR PÉREZ GARCÍA, sino un conjunto de pruebas que conducen a cerrar el círculo de una imputación en su contra, las cuales por su gravedad, coherencia y univocidad, permiten concluir que propició la ejecución de un conjunto de homicidios y lesiones personales que por su interferencia con los derechos humanos se congloba en lo que para la historia se denomina la "Masacre de Segovia."

Sexto. Como conclusión, la Sala encuentra que se configuran los presupuestos sustanciales del artículo 232 de la ley 600 de 2000 para condenar al procesado por la comisión del concurso de conductas punibles de concierto para delinquir, homicidio agravado y lesiones personales agravadas en concurso material y heterogéneo, que se consumaron el 11 de noviembre de 1988 en el municipio de Segovia.

En relación con esta determinación es necesario señalar lo siguiente: Para la Sala no hay duda que los homicidios y lesiones personales fueron ejecutados materialmente por un colectivo criminal que en el lenguaje actual se identifica como "grupo armado al margen de la ley". También es evidente con fundamento en la prueba analizada, que este grupo armado ilegal tuvo una existencia prolongada en el tiempo e hizo parte de una conspiración mayor que propició acciones de exterminio contra ciudadanos y miembros de la Unión Patriótica que no compartían sus prácticas y políticas excluyentes.

${ }^{47}$ El doctor Gaviria Zapata manifestó: "Preguntado por la defensa: Le pregunto en su primera y segunda reunión que usted asistió personas o grupos políticos hicieron relación a la participación de César Pérez a la gravedad que se estaba viviendo. Contesto: Jamás en ninguna de esas veces se Mencionó nada; eso se vino a mencionar mucho tiempo después no sabría precisar en el tiempo cuándo fue pero lo hizo un diputado de la época el doctor Gabriel Jaime Santamaría en un discurso público que él era diputado de la UP años después diciendo que la masacre de Segovia, el que tenía que ver era César Pérez García y él, que era el amigo de César Pérez García, nos encontramos con él en Medellín y le dijo a César ahí te metí en un baile vas haber como te vas a salir de el porque en el discurso dije que el partido liberal en cabeza tuya era el que tenía que ver con la masacre de Segovia y se puso a reír y eso quedó allí no se le dio importancia y más sin embargo eso con el tiempo fue creciendo esta bola de nieve hasta ver las circunstancias en que se está ahora...."declaración de septiembre 16 de 2010, folio 99 C.O. 2. 
Asimismo, la Sala concluye que la acción del grupo armado ilegal, apreciada en un contexto histórico y social signado por la desaparición y muerte de ciudadanos pertenecientes a determinadas corrientes ideológicas, se constituye en un acto más de un conjunto de acciones idénticas que denotan la sistematicidad y generalidad del ataque, características de las graves violaciones a los derechos humanos.

Desde esta perspectiva, entonces, es posible apreciar el comportamiento como un estado de cosas disvalioso que afecta el bien jurídico desde una óptica que involucra un conjunto de acciones de las cuales fueron víctimas, en todo el territorio nacional, personas vinculadas con la Unión Patriótica; circunstancia, sin duda, que propició el empleo de un aparato armado mediante la inducción a su principal cabecilla para la realización de ese específico acto.

En ese orden de ideas, haber persuadido al máximo jefe del grupo paramilitar para desplegar una acción con múltiples víctimas en ese contexto histórico, denota conocimiento del ataque, de su sistematicidad y del momento histórico en el cual la conducta se inscribe, y voluntad de obrar de acuerdo con esa comprensión, cuestiones que sin duda CESAR PEREZ GARCIA debía saber por su participación en el quehacer político y por las altas responsabilidades estatales que desempeñaba.

Por esa razón la condena por la comisión de los delitos de concierto para delinquir, homicidio agravado y lesiones personales agravadas es inexorable.

Séptimo. De acuerdo con lo expresado en apartes anteriores, la Sala fijará la pena con base en las normas del decreto 100 de 1980 y tendrá en cuenta para ello las consecuencias que emergen de los institutos de la participación y del concurso de delitos, de acuerdo a los términos de la acusación.

El decreto 100 de 1980 y la Ley 599 de 2000 definen diferentes formas de participación con fundamento en el principio de accesoriedad. Así, el artículo 23 del Decreto 100 de 1980 señala que son autores quienes realizan la conducta o quienes determinan a otro a realizarla. La ley 599 de 2000, por su parte, con mayor precisión delimitó la autoría y participación, y distinguió la determinación, la complicidad y la intervención.

En ambas legislaciones, la determinación y la autoría tienen la misma respuesta punitiva, aun cuando ontológicamente son diferentes, pero en el nivel de la participación hay que convenir en que determinar, según el diccionario de la lengua española, es "hacer tomar una resolución", justamente lo que desde el ámbito probatorio realizó el ex representante a la Cámara CÉSAR PÉREZ GARCÍA.

Si algo queda claro del análisis probatorio es que CÉSAR PÉREZ GARCÍA, además de incurrir en la comisión del delito de concierto para delinquir, 
también persuadió a la máxima jerarquía del grupo armado dirigido por Henry de Jesús Pérez a ejecutar la acción del 11 de noviembre de 1988, conducta que se tradujo en múltiples homicidios agravados y en lesiones personales agravadas en relación con tantas personas plenamente individualizadas, asumiendo por su cuenta y riesgo las consecuencias y resultados de semejante acto.

En conclusión, en el caso bajo examen la prueba analizada conduce a tener plena certeza de la determinación de la conducta que surge de reuniones y de consensos entre CÉSAR AUGUSTO PÉREZ GARCÍA, Henry Pérez y Fidel Castaño, para demandar de ellos la realización de la masacre en el municipio de Segovia, como retaliación contra la comunidad segoviana por haber apoyado en las elecciones del año 1988 el proyecto político de la Unión Patriótica, que según se ha expuesto dio lugar al homicidio y lesiones personales de diversas personas.

Por lo tanto, de acuerdo con la teoría del conocimiento y los grados de aproximación racional a la verdad que cada momento procesal exige, es evidente que existe el mérito suficiente para emitir una sentencia de condena, con fundamento en la prueba allegada al expediente que permite obtener la certeza para arribar a la determinación que se adopta.

Es palpable que la conducta típica del ex parlamentario es antijurídica y culpable, pues con su conducta desencadenó un proceso que interfirió y lesionó los bienes jurídicos de la seguridad pública y los personalísimos de la vida e integridad personal de las personas identificadas en esta decisión, actos que por su gravedad y por ser consecuencia de una operación sistemática y generalizada constituyen una grave vulneración a los derechos humanos.

En este sentido la antijuridicidad del comportamiento, según lo expresó la Sala en otros apartes, no se puede apreciar a partir exclusivamente de la lesividad individual del injusto, pues la sistematicidad y generalidad inherente a la conducta conlleva un desvalor que incorpora las implicaciones sociales de la conducta, que es precisamente lo que permite incluir la filosofía de los derechos humanos a la hora de apreciar la magnitud de la antijuridicidad del comportamiento por el cual se condenará al acusado.

Precisamente la lesividad del comportamiento conllevó a que la Sala adscribiera el comportamiento a la gama de graves atentados contra los derechos humanos por la sistematicidad y generalidad del ataque, cuestión que desde la perspectiva del derecho penal interno corresponde en su desvalor a un concurso de conductas punibles entre las que se incluyen comportamientos agravados contra la vida y la integridad personal, tal como lo precisó la Sala al resolver las nulidades propuestas por la defensa en la audiencia preparatoria.

En fin, queda desvirtuada la presunción de inocencia de CÉSAR AUGUSTO PÉREZ GARCÍA y por eso, demostrada con certeza su responsabilidad 
penal, no hay lugar a la absolución que reclama su defensa. Conforme con la acusación, como se ha indicado, la Corte lo encuentra responsable de la comisión de conductas punibles de concierto para delinquir, Homicidio agravado y Lesiones personales agravadas, como igualmente lo solicitaron el Ministerio Público y el representante de las víctimas.

De otra parte, es importante determinar que a lo largo del proceso únicamente se logró acreditar las lesiones de algunas de las numerosas personas que resultaron perjudicadas con estos hechos, pues debido al tiempo transcurrido no se pudo acopiar la información que permitiera establecer el daño causado y la incapacidad fijada para con fundamento en ello efectuar la adecuación típica correspondiente.

Al no contar con los dictámenes médicos alusivos a las consecuencias definitivas no puede presumir la Sala que todos los que resultaron afectados en esos hechos soportaron la misma determinación médico legal.

Bajo ese entendido se puede observar que únicamente obran en el proceso dictámenes provisionales y definitivos respecto de algunos de los afectados, los cuales pasan a relacionarse así: Mario de Jesús Villa, incapacidad de 4 días, no hay secuelas ${ }^{48}$; Johny Jaramillo Restrepo, 6 días de incapacidad ${ }^{49}$; Norbey Jiménez, 15 días, requiere segundo reconocimiento; ${ }^{50}$ Macleris de Jesús Brand Soto, 18 días de incapacidad, para segundo reconocimiento ${ }^{51}$; Guillermo Alzate Fonnegra, incapacidad de 20 días y requiere segundo reconocimiento, ${ }^{52}$ Miguel Ángel Carillo, ${ }^{53}$ incapacidad 30 días para segundo reconocimiento; José Antonio Palacios Bohórquez ${ }^{54}$, incapacidad de 20 días, requiere nuevo reconocimiento; Olga Palacios San Martín ${ }^{55}$ incapacidad 20 días, requiere segundo reconocimiento.

No sobra precisar que si bien las lesiones personales imputadas al procesado requieren querella como requisito de procedibilidad para incoar la acción, resultaría ilógico en este caso exigir el cumplimiento del mismo, toda vez que al considerarse estas conductas como de lesa humanidad la existencia de aquél presupuesto no se compadece con la magnitud de la lesión jurídica que un hecho de esta naturaleza comporta.

Bajo esa consideración, para cuantificar la pena, recuérdese que al doctor Pérez García se le declarará responsable de un concurso homogéneo y heterogéneo de conductas punibles de concierto para delinquir, homicidio

\footnotetext{
${ }^{48}$ Anexo 4 folio 143.

${ }^{49}$ Anexo 4 folio 144.

${ }^{50}$ Anexo 4 folio 149 y anexo 7 folio 44.

${ }^{51}$ Anexo 7 folio 8.

${ }^{52}$ Anexo 1 folio 8.

${ }^{53}$ Anexo 1 folio 9.

${ }^{54}$ Anexo 1 folio 9.

${ }^{55}$ Anexo 1 folio 10.
} 
agravado y lesiones personales agravadas, de las cuales la más grave es el atentado contra la vida descrito en ese entonces en el artículo 324 del Decreto 100 de 1980 y sancionado para la época con una pena de dieciséis (16) a treinta (30) años de prisión. ${ }^{56}$

Por la gravedad de la conducta y su dimensión antijurídica, a la cual ya se ha hecho referencia; la forma de ejecución del comportamiento, la intensidad del dolo y el daño causado, la pena para el delito de homicidio, que es la conducta más grave, se fijará en 276 meses, que corresponde al máximo del primer cuarto medio; es decir, en 23 años.

En ello debe tenerse en cuenta la agravante consistente en la posición distinguida que el delincuente ocupe en la sociedad, ${ }^{57}$ dado que para la época en que se perpetró la masacre de Segovia, CÉSAR PÉREZ GARCÍA era Presidente de la Cámara de Representantes y destacado miembro del Partido Liberal, cuestión esta última que sin duda influyó en la comisión de la conducta, como quedó expuesto en esta decisión y que a la vez en el plano de la institucionalidad le imponía deberes ante la sociedad que no se le exigen al común de los ciudadanos.

Ahora, como se trata de bienes jurídicos personalísimos, se aumentará la pena por cada uno de los homicidios hasta en otro tanto, como lo dispone el artículo 31 de la legislación citada, lo cual implica que la misma por el concurso de conductas de homicidio será de treinta años de prisión, sanción que incluye el desvalor de las conductas de concierto para delinquir y lesiones personales agravadas, en consideración a que el monto de la pena no puede sobrepasar, por virtud de lo dispuesto en el artículo 28 del decreto 100 de 1980, de 30 años de prisión.

La pena de multa será de un mil (1.000.oo) pesos a favor del Tesoro nacional, en atención a lo dispuesto en el artículo 332 del Decreto 100 de 1980.

La sanción accesoria de inhabilitación de derechos y funciones públicas, será de diez (10) años, toda vez que ese era el máximo que se establecía en la normatividad vigente para la época (Art. 50).

Aparte de otras consideraciones que son innecesarias, por el monto de la pena principal impuesta al sentenciado, no tiene derecho a la suspensión condicional de la ejecución de la pena ni a la prisión domiciliaria.

\footnotetext{
${ }^{56}$ Para el delito más grave, que es el homicidio agravado, la pena oscila entre dieciséis (16) a treinta (30) años de prisión. De acuerdo con el artículo 61 de la ley 599 de 2000, el cuarto mínimo va de 192 a 234 meses; los cuartos medios, entre 234 un día a 276 meses y 276 y un día a 318 meses; y el último cuarto, entre 318 meses y un día a 360 meses.

${ }^{57}$ Artículo 66 numeral 11 de la Ley 100 de 1980.
} 


\section{Séptimo. Indemnización de perjuicios}

Varias de las víctimas llegaron al proceso mediante la demanda de constitución de parte civil; son ellas:

Demanda de Consuelo de Jesús Orozco de Agudelo, representada por el abogado Víctor Rodolfo Barrera Benavides; reclama perjuicios materiales y morales los que determina así:

Materiales: El sustento para la señora Consuelo Orozco y sus hijos menores que al momento de los hechos provenía del trabajo de Oscar Agudelo. Los gastos de traslado del pueblo para salvaguardar su vida y la de sus hijos. Los gastos de educación. Estima los perjuicios en cien millones de pesos (\$ 100.000.000.00).

Morales. Originados en los trastornos psíquicos sufridos por la accionante, los cuales estima en cuatro mil (4.000) gramos de oro.

Demanda de María Constanza Restrepo Cadavid, Arminda de Jesús Restrepo Cadavid, María Emilse Restrepo Cadavid, Luz Marina Restrepo Cadavid, María Graciela Restrepo Cadavid, Esperanza Noris Restrepo Cadavid, Luz Marina Escobar Restrepo y María Patricia Restrepo, representados por Luz Estela Aponte Jaramillo.

Morales. Reclama perjuicios para Esperanza Noris Restrepo Cadavid, representados en el dolor por la pérdida de su padre y sus dos hermanos, las lesiones de su hermana María Emilse Restrepo, las afectaciones de su progenitora Ana Rosa Cadavid, los cuales estima en la suma de cuatrocientos ocho millones de pesos (\$408.000.000).

Para Luz Marina Escobar Cardona reclama una suma idéntica como consecuencia del dolor por haber sido estigmatizada por su pertenencia a la UP; el dolor moral que le causó la tentativa de Homicidio, el desprendimiento de su hijo y su esposo.

Adiciona la demanda de parte civil reclamando perjuicios para la señora María Patricia Restrepo, esgrimiendo que su entorno familiar se deterioró y las aflicciones a que se vio avocada por haber dado muerte a sus congéneres a causa de su militancia en la UP, viéndose privada de su familia.

Además, en su escrito recalcula el valor antes solicitado, estimándolo en la suma de quinientos treinta y cinco millones seis cientos mil pesos (\$535.600.000.00), por concepto de perjuicios morales y como daño a la vida de relación la misma suma, los cuales solicita para Esperanza Noris Restrepo Cadavid, Luz Marina Escobar Cardona y María Patricia Restrepo.

Acerca de las restantes poderdantes refiere que ya fueron indemnizadas en proceso de reparación directa que se inició contra el Estado. 


\section{Demanda de María Farney Castaño de Idárraga, Wilmer Idárraga Castaño, Jhoanny Idárraga Castaño, representados por Efraín Caicedo Fraide.}

Morales. Reclama como daño moral para María Farney Castaño la suma de cuatrocientos (400) salarios mínimos legales mensuales vigentes y para sus dos hijos a cada uno la suma de trescientos (300) salarios mínimos legales mensuales vigentes.

Materiales. Como lucro cesante para la citada mujer por valor de \$ 90.458.462. Para Wilmer Idárraga Castaño $\$ 17.397 .987 .50$ y para Jhoanny Idárraga Castaño la suma de \$6.882.975.

Teniendo como fundamento lo anterior se debe señalar que los perjuicios materiales que estimaron las diferentes partes civiles reconocidas en el proceso, no fueron probados por quienes tenían la carga específica de acreditarlos.

En efecto, nada hicieron con ese propósito los representantes de las víctimas, como era su deber, para dotar a la Sala de los elementos de juicio suficientes con miras a soportar su solicitud indemnizatoria. Se les olvidó que no basta, según lo ha señalado la Jurisprudencia de esta Sala y la Corte Constitucional, con la simple estimación de los perjuicios, sino que ellos se deben acreditar por los medios idóneos con el fin de establecerse la relación que pueda existir entre el daño causado y su valor. Por ejemplo, no se acreditaron las labores ejercidas por los causantes, la dependencia económica que se tenía de las víctimas y los gastos en que se incurrió con ocasión del deceso.

La ley establece que incumbe a las partes probar el supuesto de hecho de las normas que consagran los efectos jurídicos que ellas persiguen (artículo 177 del C de P.C). En consecuencia, quien pretende judicialmente la reparación de un daño debe probarlo, toda vez que este elemento, como quedó explicado, es presupuesto indispensable de la obligación de indemnizar.

“...la liquidación de los perjuicios ocasionados por el delito se debe hacer de acuerdo con lo acreditado en el proceso penal, como quiera que la acción civil dentro del proceso penal depende de que la parte civil muestre la existencia de los daños cuya reparación reclama y el monto al que ascienden...Así, las víctimas y perjudicados con el delito, como manifestación del derecho a acceder a la administración de justicia, tienen también un derecho constitucional a participar en el proceso penal que el Estado está en la obligación de adelantar, derecho que no debe limitarse a la declaratoria de responsabilidad penal, sino que, además, ha de extenderse a la obtención de la reparación del daño cuando este se encuentre probado.....Al margen del derecho que le asiste a la víctima del delito para constituirse en parte civil dentro del proceso penal y con el propósito de garantizar la reparación de los daños causados con el delito, la ley le impone al juez la obligación de liquidar los perjuicios en todos los casos en que se profiera sentencia condenatoria y se encuentre demostrada la existencia de los mismos... ${ }^{58}$

${ }^{58}$ Corte Constitucional, referencia: expediente D-4020 Demanda de inconstitucionalidad contra el artículo 97 de la Ley 599 de 2000, “( p)or la cual se expide el Código Penal". Actor: 
No se puede olvidar que le corresponde la carga de la prueba en materia civil a quien formula la pretensión. En este caso los accionantes se conformaron con presentar la demanda, pero sin realizar actividades procesales para probar sus pretensiones; por ello, mal podría la Sala ahora, en forma oficiosa, entrar a determinar unos perjuicios materiales sin que exista el supuesto probatorio legal para ello.

"...Al margen del derecho que le asiste a la víctima del delito para constituirse en parte civil dentro del proceso penal y con el propósito de garantizar la reparación de los daños causados con el delito, la ley le impone al juez la obligación de liquidar los perjuicios en todos los casos en que se profiera sentencia condenatoria y se encuentre demostrada la existencia de los mismos.... y perjudicados con el delito, como manifestación del derecho a acceder a la administración de justicia, tienen también un derecho constitucional a participar en el proceso penal que el Estado está en la obligación de adelantar, derecho que no debe limitarse a la declaratoria de responsabilidad penal, sino que, además, ha de extenderse a la obtención de la reparación del daño cuando este se encuentre probado..." 59

Con fundamento en los anteriores enunciados y como quiera que no se demostró en forma fehaciente y concreta la causación de algunos de los perjuicios solicitados, se procederá a fijar la indemnización desde el punto de vista del daño moral, quedando comprendido dentro del mismo el daño a la vida en relación.

"....La armonización de los textos legales citados permite inferir que las exigencias para la demostración y liquidación del daño se predican del perjuicio material, dejando al Juez la facultad de fijar los no valorables pecuniariamente que son los morales de carácter subjetivado en razón a que afectan el fuero interno de las víctimas o perjudicados, ya que se traducen en la tristeza, el dolor, la congoja o la aflicción que sienten las personas como consecuencia directa e inmediata del delito, cuyo único límite está determinado por la ley a partir de factores relacionados con la naturaleza de la conducta y la magnitud del daño causado..."60

Debe precisarse, como lo ha expresado la Sala de antaño, que por haber ocurrido los hechos en vigencia del decreto 100 de 1980, se debe acudir a dicha legislación, aun tratándose de liquidación de perjuicios:

“....La Sala ha tenido oportunidad de ocuparse sobre el particular (Casaciones 23687/06, 24985/07 29186/08, entre otras), bajo el supuesto de entender que por razones de favorabilidad no es dable aplicarle al procesado preceptos que van

Camilo Andrés Baracaldo Cárdenas Magistrado Ponente: Manuel José Cepeda Espinosa. Bogotá, D.C., C- 916 DEL veintinueve (29) de octubre de dos mil dos (2002).

${ }_{59}$ Corte Constitucional, Referencia: expediente D-4020 Demanda de inconstitucionalidad contra el artículo 97 de la Ley 599 de 2000, "Por la cual se expide el Código Penal". Actor: Camilo Andrés Baracaldo Cárdenas Magistrado Ponente: Manuel José Cepeda Espinosa, Bogotá, D.C., C- 916 DEL veintinueve (29) de octubre de dos mil dos (2002).

${ }^{60}$ Corte Suprema de Justicia, Sala de Casación Penal, diciembre 12 de 2005, rad. 24.011. 
en detrimento de su situación personal, en forma tal que si la nueva normativa contempla la posibilidad de que las consecuencias -aún civiles-, del hecho punible lo avoquen a una mayor drasticidad, deben desecharse y preferirse aquellas más benévolas a su situación...., En todo caso, la doctrina de la Sala, acudiendo al criterio fijado en diversos proveídos, según el cual "se opta por razón de la favorabilidad por la penalidad del anterior ordenamiento sustantivo" y para el efecto se establece que "se hace necesario también verificar cómo estaban previstas las consecuencias civiles del delito y principalmente los montos máximos permitidos" (Cas. 29985/07)..."61

Por lo anterior, con el criterio que viene exponiéndose en cuanto a la aplicación del decreto 100 de 1980 tratándose de liquidación de perjuicios y asumiendo los pronunciamientos del Consejo de Estado, ${ }^{62}$ en punto de liquidación de perjuicios morales que se deben reconocer, liquidar y pagar en salarios mínimos para dar cumplimiento a los principios de equidad y reparación integral del daño, abandonando el criterio de la condena en gramos de oro, se procederá a tomar como base para su liquidación el valor del salario mínimo legal mensual fijado para el año de 1988, el cual era de $\$ 25.637 .40$ pesos.

Resulta de las exposiciones ofrecidas en el proceso, en particular respecto de María Patricia Restrepo, Esperanza Noris Restrepo Cadavid y Luz Marina Escobar Cardona, que se encuentran acreditados tanto los perjuicios morales como los referidos al daño en la vida de relación, toda vez que sus vidas, luego de los cruentos hechos, se vieron seriamente afectadas, no volvieron a ser las mismas, fueron separados de sus familias y mantuvieron, algunas de ellas, sentimientos de culpa, considerándose causantes de las muertes de sus congéneres debido a la militancia que tuvieron en la UP. Ello modificó su comportamiento, vivieron con temor y zozobra, le dieron un nuevo norte a su vida, produjo un alejamiento social que resultó perjudicial para su desarrollo emocional.

Fueron estigmatizadas por haber pertenecido, militado o apoyado a la Unión Patriótica, se les tildó de guerrilleras, lo cual obviamente generó un temor que obligó a algunas de ellas a su desplazamiento o al hacinamiento ante la pérdida de oportunidades laborales debido a los señalamientos que se les hacía. Sobre este particular la Corte, Sala Civil, expresó el criterio que pasa a relacionarse el cual fue recogido por la Sala Penal en su decisión del pasado 25 de agosto de 201063: "...Como se observa, a diferencia del daño moral, que corresponde a la órbita subjetiva, intima o interna del individuo, el daño a la vida de relación constituye una afectación a la esfera exterior de la persona, que puede verse alterada, en mayor o menor grado, a causa de una lesión infligida a los bienes de la personalidad o a otro tipo de intereses jurídicos, en desmedro de lo que

${ }^{61}$ Corte Suprema de Justicia, Sala de Casación Penal, septiembre 17 e 2008, Rad. 27.107.

${ }^{62}$ Consejo de Estado, Sección Tercera, proceso No. 13.232 - 15646 de 6 de septiembre del 2001 en el mismo sentido sentencias números 13767, 12013, 13131.

${ }^{63}$ Ver Casación Rad 33833. 
la Corte en su momento denominó "actividad social no patrimonial.....Dicho con otras palabras, esta especie de perjuicio puede evidenciarse en la disminución o deterioro de la calidad de vida de la víctima, en la pérdida o dificultad de establecer contacto o relacionarse con las personas y cosas, en orden a disfrutar de una existencia corriente, como también en la privación que padece el afectado para desplegar las más elementales conductas que en forma cotidiana o habitual marcan su realidad. Podría decirse que quien sufre un daño a la vida de relación se ve forzado a llevar una existencia en condiciones más complicadas o exigentes que los demás, como quiera que debe enfrentar circunstancias y barreras anormales, a causa de las cuales hasta lo más simple se puede tornar difícil. Por lo mismo, recalca la Corte, la calidad de vida se ve reducida, al paso que las posibilidades, opciones, proyectos y aspiraciones desaparecen definitivamente o su nivel de dificultad aumenta considerablemente. Es así como de un momento a otro la víctima encontrará injustificadamente en su camino obstáculos, preocupaciones y vicisitudes que antes no tenía, lo que cierra o entorpece su acceso a la cultura, al placer, a la comunicación, al entretenimiento, a la ciencia, al desarrollo y, en fin, a todo lo que supone una existencia normal, con las correlativas insatisfacciones, frustraciones y profundo malestar...En este orden de ideas, la Corte, a manera de compendio, puntualiza que el daño a la vida de relación se distingue por las siguientes características o particularidades: a) tiene naturaleza extrapatrimonial o inmaterial, en tanto que incide o se proyecta sobre intereses, derechos o bienes cuya apreciación es económicamente inasible, por lo que no es dable efectuar una mensura que alcance a reparar en términos absolutos la intensidad del daño causado; $\boldsymbol{b}$ ) adquiere trascendencia o se refleja sobre la esfera externa del individuo, situación que también lo diferencia del perjuicio moral propiamente dicho; c) en las situaciones de la vida práctica o en el desenvolvimiento que el afectado tiene en el entorno personal, familiar o social se manifiesta en impedimentos, exigencias, dificultades, privaciones, vicisitudes, limitaciones o alteraciones, temporales o definitivas, de mayor o menor grado, que él debe soportar o padecer, las cuales, en todo caso, no poseen un significado o contenido monetario, productivo o económico; d) no sólo puede tener origen en lesiones o trastornos de tipo físico, corporal o psíquico, sino también en la afectación de otros bienes intangibles de la personalidad o derechos fundamentales, e incluso en la de otro tipo de intereses legítimos; e) según las circunstancias de cada caso, puede ser sufrido por la víctima directa de la lesión o por terceros que igualmente resulten afectados, como, verbigracia, el cónyuge, el compañero o la compañera permanente, los parientes cercanos o los amigos, o por aquélla y éstos; $f$ ) su reconocimiento persigue una finalidad marcadamente satisfactoria, enderezada a atemperar, lenificar o aminorar, en cuanto sea factible, los efectos negativos que de él se derivan; y g) es una noción que debe ser entendida dentro de los precisos límites y perfiles enunciados, como un daño autónomo que se refleja en la afectación de la actividad social no patrimonial de la persona, vista en sentido amplio, sin que pueda pensarse que se trata de una categoría que absorbe, excluye o descarta el reconocimiento de otras clases de daño - patrimonial o extrapatrimonial - que posean alcance y contenido disímil, ni confundirlo con éstos, como si se tratara de una inaceptable amalgama de conceptos, puesto que una indebida interpretación 
conduciría a que no pudiera cumplirse con la reparación integral ordenada por la ley y la equidad, como infortunadamente ha ocurrido en algunos casos, en franco desmedro de los derechos que en todo momento han de asistir a las víctimas...."64

Por concepto, entonces, de perjuicios morales, quedando comprendidos dentro de ellos el daño a la vida de relación, se establecerán los siguientes montos expresados en salarios mínimos legales mensuales vigentes para la fecha de los hechos:

Para Esperanza Noris Restrepo 800 salarios mínimos legales mensuales; para Luz Marina Escobar Cardona 500 y para María Patricia Restrepo 700, los cuales deberán ser indexados al momento de la liquidación.

Por concepto de daño moral, también representado en salarios mínimos legales mensuales vigentes para la fecha de los hechos: para María Farney Castaño de Idárraga 500; para Wilmer Idárraga Castaño 400 y Jhoanny Idárraga Castaño 400, y para Consuelo de Jesús Orozco de Agudelo 500.

\section{Octavo. Determinaciones finales}

Con base en las manifestaciones expresadas en la vista pública por la señora María Emilse Restrepo Cadavid, ${ }^{65}$ en el sentido de haber recibido amenazas, se compulsarán copias a la Fiscalía General de la Nación, para que se proceda de conformidad.

Compulsar copia al Consejo Superior de la Judicatura y a la Fiscalía General de la Nación, para que se investigue la posible conducta punitiva en que pudo incurrir la abogada Gloria Rave, conforme a citas que le figuran en el informe 606784 de fecha 24 mayo de 2011, folio 22 cuaderno Reservado.

Igualmente conforme a escrito que obra en el expediente ${ }^{66}$ en el cual se pone en conocimiento unos hechos presuntamente delictivos referidos al candidato a la alcaldía de La Estrella (Antioquia), compúlsese copias para la Fiscalía General de la Nación a fin que se investigue la posible conducta en que pudo haber incurrido.

\section{DECISIÓN}

En mérito de lo expuesto, la Corte Suprema de Justicia, Sala de Casación Penal, administrando justicia en nombre de la República y por autoridad de la Ley,

\footnotetext{
${ }^{64}$ Corte Suprema de Justicia, Sala Casación Civil, M.P. César Julio Valencia Copete, Mayo 13 de 2008, Rad. 11001310300619970932701.

${ }^{65}$ Declaración en audiencia pública, enero 30 de 2012, pie de rodamiento 1.58.40.

${ }^{66}$ c.o. 13 folios 177 a 182
} 


\section{RESUELVE}

Primero: CONDENAR a CÉSAR AUGUSTO PÉREZ GARCÍA, de notas personales y civiles conocidas en el proceso, a la pena principal de treinta (30) años de prisión y a la accesoria de interdicción de derechos y funciones públicas por diez (10) años, por la comisión de los delitos de concierto para delinquir y homicidio agravado, agotado en las personas de:

Adalberto Lozano Ruiz, Carlos Enrique Restrepo Cadavid, Carlos Enrique Restrepo Pérez, Diana María Vélez, Erika Milena Marulanda, Fabio Jaramillo, Fabio Sierra Gómez, Francisco William Gómez Monsalve, Gildardo Antonio Restrepo Cadavid, Guillermo Osorio Escudero, Guillermo de Jesús Areiza, Henry Alberto Castrillón, Jairo Rodríguez Pardo, Jesús Aníbal Gómez, Jesús Antonio Benítez, Jesús Antonio García, Jesús Emilio Calle Guerra, Jesús Orlando Vásquez Zapata, Jorge Luis Puerta Londoño, José Abelardo Madrid, José Alberto Osorno Betancur, José Danilo Amariles Ceballos, Juan de Dios Palacio Múnera, Julio Martín Flórez Ortiz, Libardo Antonio Cataño Atehortúa, Luis Adalberto Lozano Ruiz, Luis Ángel de Jesús Moreno San Martín, Luis Eduardo Hincapié, Luis Eduardo Sierra, María del Carmen Idárraga, María Dolly Bustamante, María Soledad Niño, Olga Agudelo Barrientos, Oscar de Jesús Agudelo, Pablo Emilio Gómez Chaverra, Pablo Emilio Idárraga Osorio, Regina del Socorro Muñoz Mestre, Roberto Antonio Marín Osorio, Robinson de Jesús María Arena, Rosa Angélica Mazo Arango, Shirley Castaño Patiño, Vidalia Orozco Saldarriaga y tres personas más no identificadas.

Y por el concurso de lesiones personales agravadas, en perjuicio de la integridad personal de:

Mario de Jesús Villa, Johny Jaramillo Restrepo, Norbey Jiménez, Macleris de Jesús Brando Soto, Guillermo Alzate Fonnegra, Miguel Ángel Carrillo, José Antonio Palacios Bohorquez, Olga Palacios San Martín.

Segundo. Declarar, por lo expuesto en la parte motiva de esta decisión, que CÉSAR AUGUSTO PÉREZ GARCÍA no tiene derecho a la suspensión condicional de la ejecución de la pena, ni a la prisión domiciliaria.

Tercero: Condénese al señor CÉSAR AUGUSTO PÉREZ GARCÍA a pagar las siguientes sumas de dinero:

Por concepto de perjuicios morales, quedando comprendidos dentro de ellos el daño a la vida en relación, los siguientes montos expresados en salarios mínimos legales mensuales vigentes para la fecha de los hechos:

Para Esperanza Noris Restrepo 800 salarios mínimos legales mensuales; para Luz Marina Escobar Cardona 500 salarios mínimos legales mensuales y para María Patricia Restrepo 700 salarios mínimos legales mensuales, los cuales se deberán indexar al momento de la liquidación. 
Por concepto de daño moral, también representados en salarios mínimos legales mensuales vigentes para la fecha de los hechos:

Para María Farney Castaño de Idárraga 500 salarios mínimos legales mensuales; Wilmer Idárraga Castaño 400 salarios mínimos legales mensuales, Jhoanny Idárraga Castaño 400 salarios mínimos legales mensuales, y para Consuelo de Jesús Orozco de Agudelo 500 salarios mínimos legales mensuales.

Cuarto: Compúlsese las copias a que se hace alusión en el capítulo otras determinaciones.

Quinto: En firme esta providencia, remítase la actuación al Juzgado de Ejecución de Penas y Medidas de Seguridad que corresponda, para lo de su cargo.

Sexto: La Secretaría de la Sala enviará las copias del fallo a las que alude el artículo 472 del C. de P. Penal.

Contra esta sentencia no procede recurso alguno.

Cópiese, notifíquese y cúmplase. 


\section{Comentario}

\section{Metodología y eStructura del tRabajo}

El presente estudio se concentra en dos temas que constituyen los más relevantes de los abordados por la sentencia en examen y que están íntimamente relacionadas, como son: la doble subsunción y el crimen de lesa humanidad. Cada apartado se subdivide en dos con el objeto de, en primer lugar, contextualizar al lector en relación con los preceptos específicos que se cuestionan; $y$, en segundo término, de reconstruir algunos conceptos que sirven como fundamento de la crítica realizada. Con ello, por supuesto, se abandona la estructura tradicional utilizada en los comentarios jurisprudenciales con el fin de concretar, de forma específica, los apartados en discusión.

\section{ANÁLISIS}

\section{A. La doble subsunción.}

1. Referencias a la sentencia. La Sala de Casación Penal, realiza el juicio de tipicidad con referencia a los delitos internos de homicidio agravado, lesiones personales y concierto para delinquir agravado. Nos centramos en los dos primeros, que son catalogados por dicha Corporación como crímenes de lesa humanidad. Lo anterior pues la providencia afirma: "Luego de presentadas las alegaciones correspondientes, el 14 de marzo de 2011 (se) calificó el mérito del sumario, acusando a CÉSAR PÉREZ GARCÍA. En la providencia la Corte se refirió a los hechos ocurridos el 11 de noviembre de 1988 en Segovia, los cuales tipificó como un concurso de delitos de homicidio agravado y lesiones personales, comportamientos que estimó constituían por su gravedad y sistematicidad, delitos de lesa humanidad, bajo el epígrafe de "Masacre de Segovia". Igualmente le fue imputado el delito de concierto para delinquir agravado".

A su vez, se agregó: “(...) desde este punto de vista es posible conferirle a delitos que en el ámbito del derecho penal común se denominan "homicidios o lesiones personales", la categoría de delitos de lesa humanidad (...)". En la misma línea argumentativa, concluyó: "(...) se configuran los presupuestos sustanciales del artículo 232 de la ley 600 de 2000 para condenar al procesado por la comisión del concurso de conductas punibles de concierto para delinquir, homicidio agravado y lesiones personales agravadas en concurso material y heterogéneo, que se consumaron el 11 de noviembre de 1988 en el municipio de Segovia".

Agregó, finalmente, que: "El 13 de mayo de 2010 la Sala avocó conocimiento y dispuso continuar con la investigación por tratarse de una conducta imprescriptible. No sobra precisar que si bien las lesiones personales imputadas al procesado requieren querella como requisito de procedibilidad para incoar la acción, resultaría ilógico en este caso exigir el cumplimiento del mismo, toda vez que al considerarse estas conductas como de lesa humanidad la existencia de aquél presupuesto no se compadece con la magnitud de la lesión jurídica que un hecho de esta naturaleza comporta". 
2. Consideraciones conceptuales y análisis crítico. Frente a estas argumentaciones, oportuno y necesario se torna retomar el criterio de la doble subsunción propuesto por Malarino para confrontar, de forma sucinta pero crítica, la forma en que la providencia subsume la conducta en dos preceptos distintos, sin seguir un criterio único en esta materia. El criterio de doble subsunción, recuérdese, se basa en "la combinación entre derecho interno y derecho internacional $(\ldots)^{\prime \prime}$, el cual "(...) se da tal manera que el segundo se aplica en aquellos aspectos en los cuales la utilización del primero conduciría a obstaculizar la persecución penal" ${ }^{2}$, generando así "(...) una subsunción primaria de tipificación y sanción por las leyes locales y una subsunción secundaria de cualificación por las normas internacionales"

La asunción del criterio de la doble subsunción es evidente en los extractos trascritos en precedencia, puesto que la Sala de Casación Penal subsumió la conducta concreta en los preceptos de la ley interna (Código Penal Colombiano) bajo el juicio de tipicidad ${ }^{4}$ de los tipos internos de homicidio agravado y lesiones personales, pero además calificó dichas conductas en el género de crímenes de lesa humanidad. No obstante, en el Derecho penal internacional las descripciones típicas utilizadas por la Corte Suprema parecen ajenas a los actos constitutivos de crímenes de lesa humanidad que incluye el Estatuto de Roma en su artículo 7, en cuyo primer apartado se regulan en los siguientes términos: "Artículo 7. Crímenes de lesa humanidad. 1. A los efectos del presente Estatuto, se entenderá por "crimen de lesa humanidad" cualquiera de los actos siguientes cuando se cometa como parte de un ataque generalizado o sistemático contra una población civil y con conocimiento de dicho ataque: a) Asesinato; b) Exterminio; c) Esclavitud; d) Deportación o traslado forzoso de población; e) Encarcelación u otra privación grave de la libertad física en violación de normas fundamentales de derecho internacional; f) Tortura; g) Violación, esclavitud sexual, prostitución forzada, embarazo forzado, esterilización forzada o cualquier otra forma de violencia sexual de gravedad comparable; $h$ ) Persecución de un grupo o colectividad con identidad propia fundada en motivos políticos, raciales, nacionales, étnicos, culturales, religiosos, de género definido en el párrafo 3, u otros motivos universalmente reconocidos como inaceptables con arreglo al derecho internacional, en conexión con cualquier acto mencionado en el presente párrafo o con cualquier crimen de la competencia de la Corte; i) Desaparición forzada de personas; j) El crimen de apartheid; k) Otros actos inhumanos de carácter similar que causen intencionalmente grandes sufrimientos o atenten gravemente contra la integridad física o la salud mental o física. (...)".

${ }^{1}$ MALARINO, Ezequiel. El crimen contra la humanidad de desaparición forzada de personas en la jurisprudencia argentina: algunos problemas en relación con el principio de legalidad. En: MALARINO, Ezequiel. Derechos Humanos y Derecho penal. Bogotá: Editorial Ibáñez y Pontificia Universidad Javeriana, 2012. p. 97.

${ }^{2}$ Idem.

${ }^{3}$ Ibidem.

${ }^{4}$ VELÁSQUEZ, Fernando. Derecho penal. Parte general. Medellín: Librería Jurídica Comlibros, 2.009. p. 554 y sigtes. 
Así, de acuerdo a las conductas descritas en los hechos expuestos en la sentencia, las más cercanas podrían ser la de asesinato del apartado (a), en relación con el homicidio agravado, y la de otros actos inhumanos del apartado (k), respecto a las lesiones personales agravadas, por lo cual resulta impreciso el juicio de analogía que se hizo, pues aparte de que son normas distintas tienen redacciones y elementos típicos muy distintos. Es más, de manera muy extraña, en esta sentencia no se explica de forma convincente por qué se utiliza un doble juicio de subsunción cuando se mezclan dos normas totalmente distintas, es decir, el apartado 1 del artículo 7 del Estatuto de Roma y las conductas descritas en el Código Penal colombiano. Nótese que la misma jurisprudencia solo admite la combinación de algunos preceptos normativos en casos de favorabilidad penal, en aplicación del concepto de lex tertia ${ }^{5}$, el cual no viene al caso en estudio por ser presupuestos fácticos totalmente distintos.

Es más: A pesar de que no se tienen en cuenta las conductas y los elementos de los crímenes concretos ${ }^{6}$, sí se utilizan como fuente cualitativa institutos como los de la imprescriptibilidad y la prohibición de desistimiento de la acción penal, con fundamento en el Estatuto de Roma. Desde luego, si se hubiese querido considerar exclusivamente su cualificación como de crímenes de imprescriptibles, habría podido utilizar como fuente normativa la Convención sobre la imprescriptibilidad de los crímenes de guerra y de los crímenes de lesa humanidad de $1968^{7}$, pero siempre y cuando Colombia hubiese firmado y ratificado dicha Convención, lo cual no ocurrió; sin embargo, nada de ello refiere la Corte Suprema en su sentencia.

Así mismo, como criterio adicional habría podido fundamentar la imprescriptibilidad en una presunta conducta de ius cogens reconocida por algunos órganos internacionales, lo cual hubiese sido un poco más difícil de discutir, pero tampoco fue referido por la Corte.

\section{B. El crimen de lesa humanidad.}

1. Referencias a la sentencia. El proveído utiliza el criterio del elemento contextual para poder encuadrar dichas conductas como crímenes de lesa humanidad. En ese sentido, afirmó lo siguiente: "Claro, porque según lo ha definido la Sala, un delito de homicidio se cataloga crimen de lesa humanidad, no por la gravedad intrínseca que una conducta de tal naturaleza conlleva o por la importancia individual de la víctima, sino por la sistematicidad de su ejecución que en muchos casos devela una compleja operación criminal". Incluso,

\footnotetext{
${ }^{5}$ Sentencia de la Sala de Casación Penal de la Corte Suprema de Justicia del tres de septiembre de 2.001, radicado: 16.837 .

6 Véase los elementos de los crímenes. [en línea] «http://www.icc-cpi.int/nr/ rdonlyres /336923d8-a6ad-40ec-ad7b-45bf9de73d56/0/elementsofcrimeseng.pdf».

${ }^{7}$ La versión en español está disponible en línea: «http:/ / www2.ohchr.org/spanish/ law/crimenes_guerra.htm».
} 
en relación con su propio precedente, añadió: "Es más, la consideración que ha hecho la Sala de los acontecimientos ocurridos en el municipio de Segovia como delitos de lesa humanidad, en atención a que este suceso fue consecuencia de un ataque sistemático y generalizado contra la población civil, supone necesariamente un acuerdo de voluntades que permanece en el tiempo y que afecta la seguridad pública, bien jurídico cuyo riesgo se incrementó por la persistencia de las acciones de este grupo ilegal".

Asimismo, al justificar la subsunción en la categoría de crímenes de lesa humanidad, tajantemente dijo: "Claro, porque según lo ha definido la Sala, un delito de homicidio se cataloga crimen de lesa humanidad, no por la gravedad intrínseca que una conducta de tal naturaleza conlleva o por la importancia individual de la víctima, sino por la sistematicidad de su ejecución que en muchos casos devela una compleja operación criminal, que en este caso tuvo como objetivo el grupo político de la Unión Patriótica. En eso no hay duda: la "Masacre de Segovia" no es un acontecimiento que se pueda separar de lo ocurrido en esa época en el contexto nacional, dado que se constituye en un episodio más de un conjunto de acciones que llevaron incluso al asilo a muchos dirigentes con el fin de salvar sus vidas, entre ellas la misma Rita Ivonne Areiza, ex alcaldesa del municipio escenario de los hechos".

A su vez, y con el fin de probar la existencia de dicho elemento, en la mencionada sentencia se expone: "La sistematicidad como componente esencial de la acción en el lenguaje de la infracción a los derechos humanos la ilustra con propiedad Hernán Motta Motta -miembro de ese partido y ex representante a la Cámara, exiliado por la persecución de que fue objeto-, como el epílogo de una serie de atentados contra ese grupo político, o Aída Abella, también asilada por su pertenencia a la exterminada Unión Patriótica, pese a que la totalidad de los muertos no pertenecían a esa colectividad". En el mismo sentido, sostiene: "Es más, la Corte Interamericana en decisión del 26 de mayo de 2010 se refirió a la sistematicidad del ataque como elemento central de acciones de las que fueron víctimas miembros de la Unión Patriótica, lo cual no deja dudas de la estructura y generalidad del ataque, elemento esencial en la configuración del delito de lesa humanidad. A su vez, reiterando lo ya citado, afirmó: "En efecto, según lo ha explicado la Corte, a la hora de establecer principios en el caso de graves infracciones a los derechos humanos, los crímenes de lesa humanidad están asociados más que con la existencia de un conflicto armado o con la gravedad inherente de una determinada conducta, con la sistematicidad a manera de elemento material del ataque, y con el conocimiento como componente subjetivo de la acción, características a las que con conocimiento de causa se refiere el ex representante Motta Motta en su declaración y la Corte Interamericana en la decisión indicada".

Finalmente, en la misma línea argumentativa, se asegura que: "Desde este punto de vista es posible conferirle a delitos que en el ámbito del derecho penal común se denominan homicidios o lesiones personales, la categoría de delitos de lesa humanidad, tanto más si para la época de su comisión, 
Colombia ya había suscrito tratados que acentúan la sistematicidad y generalidad del ataque como criterios diferenciadores entre un delito común y conductas que en el nivel de la macro criminalidad afectan de manera superlativa los derechos humanos".

2. Consideraciones conceptuales y análisis crítico. Los crímenes se pueden catalogar para este estudio en delitos de derecho interno, crímenes de trascendencia internacional, crímenes internacionales de origen convencional distintos al Estatuto de Roma y crímenes internacionales principales (core crimes). Los delitos de derecho interno, son los concebidos dentro de cada sistema jurídico nacional, manejando distintas estructuras según la tradición jurídica a la que pertenezcan, destacándose los tres modelos que más influencia tienen, es decir, el derecho continental (civil law), el common law y el derecho penal islámico ${ }^{8}$.

En el caso en estudio, nos centraremos en los dos primeros. Dentro del derecho de tradición continental, se pueden destacar tres principales estructuras del delito, sin ánimo de entrar en mayor profundidad en el tema: 1) El sistema tripartito: este sistema concibe un delito compuesto por una acción típica, antijurídica y culpable; 2 ) el sistema bipartito: para este modelo se estructura el delito como compuesto por una fuerza física y una fuerza moral ${ }^{10}$. Y, 3) El modelo francés, en el cual se encuentran distintas estructuras, destacándose tanto las teorías bipartitas como las tripartitas ${ }^{11}$.

8 Se debe señalar que algunos autores incluyen esta tradición dentro de los antecedentes de conceptos como el mens rea en Derecho penal internacional (véase, BADAR, Mohamed Elewa. The Concept of Mens Rea in International Criminal Law: The Case for a Unified Approach. Portland: Hart Publishing, 2013. p. 22).

${ }^{9}$ Véase BORJA JIMÉNEZ, Emiliano. Algunos planteamientos dogmáticos en la teoría jurídica del delito en Alemania, Italia y España. En: Cuadernos de política criminal, no. 63,1997 .p. 40.

${ }^{10}$ Idem.

${ }^{11}$ De forma expositiva, Ambos reconstruye de la siguiente manera las principales tendencias en Francia: "es posible hoy en día distinguir en la doctrina francesa las siguientes posturas: 1) Teoría clásica de los tres elementos constitutivos del hecho punible, cuales son: "élément légal", "élément matériel" y "élément moral", "psychologique" o "intellectuel". 2) Teoría de los tres elementos constitutivos del hecho punible a los que se les une un cuarto elemento independiente, éste es, el "élément injuste". También se la denomina teoría de los cuatro elementos. 3) Teoría de los tres elementos constitutivos del hecho punible, junto al "élément injuste", pero sin el elemento legal, por encontrarse éste fuera del hecho punible, siendo en realidad entendido como una condición previa a su existencia ("préalable légal"). 4) Teoría de los dos elementos constitutivos del hecho punible (elemento material y elemento psicológico), considerando al elemento legal, al igual que la teoría anterior, como condición previa al hecho punible ("préalable légal"). 5) Teoría objetiva de los dos elementos constitutivos del hecho punible (elemento legal y elemento material) siendo el hecho punible completamente objetivo, exteriorizado a través de un acto o acción 
El derecho del common law, concibe un delito bipartito compuesto, en principio, por dos categorías específicas: el actus reus y el mens rea ${ }^{12}$. De forma general, dice Dressler, el actus reus hace referencia a la "porción física o externa del crimen"13, y el mens rea es "la característica mental o interna"14 . Esta clasificación es muy general y, en el seno de debate al respecto, cada país maneja variantes distintas y diversas discusiones académicas. Algunos consideran que el delito se divide en actus reus, mens rea y defences ${ }^{15}$, otros lo generalizan a ofensas y defensas, siendo debatido qué contiene cada uno ${ }^{16}, \sin$ perjuicio de otras clasificaciones que en un estudio más específico se puedan encontrar ${ }^{17}$. Al respecto, se debe recordar que en el Derecho penal islámico se diferencian tres tipos de crímenes: los húdud, los quisas y diyya, y los $T a^{\prime} a z i r^{18}$, y, dependiendo de la categoría a la que pertenezca, tendrá una estructura distinta de análisis que permita determinar la responsabilidad penal ${ }^{19}$.

Con base en algunos postulados del Derecho penal del common law, en el Derecho penal internacional existe un consenso más acentuado en la estructura general que se maneja, gracias a la consolidación que trató de hacer el Tribunal Penal para la Antigua Yugoslavia (TPIY ${ }^{20}$, sin perjuicio de

(material), dejando toda la faz subjetiva del hecho dentro de la culpabilidad. 6) Teoría objetiva del elemento único del hecho punible, la cual admite sólo características objetivas como elementos propios constitutivos del hecho punible ("proprements constitutifs"). Esta teoría considera al elemento legal como una condición previa y, a la faz subjetiva del hecho, como una categoría del actor ("théorie du delinquant") o bien, como una categoría de la imputación ("imputabilité"). 7) Teoría objetivosubjetiva (mixta) de los dos elementos constitutivos del hecho punible, que reconoce junto al elemento material, también al elemento moral, pero considerando las características propias del actor (por ejemplo: coacción, demencia) como una categoría independiente del delincuente" (se omiten pies de página del original). Véase, AMBOS, Kai. Observaciones a la doctrina francesa del hecho punible desde la perspectiva alemana. En: IndretPenal, 3.08, 2.008. p. 4 y 5 [en línea] «http:/ /www. indret.com/pdf/556_es.pdf».

12 Véase DRESSLER, Joshua. Understanding Criminal Law. Sixth Edition. San Francisco y New Providence: Lexis Nexis, 2012. p. 85.

13 " (...) the physical or external portion of the crime", DRESSLER, idem, p. 85.

14 " $(\ldots)$ the mental or internal feature", ibid, p. 85.

15 Véanse las referencias de AMBOS, Kai. Treatise on International Criminal Law, Volume I: Foundations and General Part. Croydon: Oxford University Press, 2013. p. 100; WERLE, Gerhard, et al. tr. María Gutiérrez et al. Tratado de Derecho Penal Internacional, 2 ed. Valencia: Tirant lo Blanch, 2011. p. 245.

${ }_{16}$ Acerca del debate contemporáneo, véase GARDNER, John. Ofensas y defensas. Madrid: Marcial Pons, 2012. p. 99 y sigtes.

${ }^{17}$ Frente a los distintas concepciones de mens rea en distintos países del Common Law, BADAR, Ob. cit., p. 31 y sigtes.

18 Véase las referencias de BADAR, Ob. cit., p. 205.

${ }^{19}$ Ibíd., p. 208.

${ }^{20}$ Véase WERLE, Ob. cit., p. 246 y sigtes.; BADAR, ibid., p. 287 y sigtes. 
que existan variantes en la academia; por ejemplo, Kai Ambos concibe una estructura bipartita compuesta por ofensas/atribución de responsabilidad (que incluye el actus reus y el mens rea) y defensas/aspectos de exclusión de responsabilidad (tanto sustanciales como procesales) ${ }^{21}$. La convergencia de los sistemas del delito del common law y del derecho continental en la Corte Penal Internacional ha generado un interesante panorama ${ }^{22}$.

Frente a la segunda categoría anunciada inicialmente, es decir, los delitos de trascendencia internacional, se debe decir, en primer lugar, que se encuentran distintas denominaciones al respecto, entre ellas, la de delitos de trascendencia internacional o la de crímenes internacionales de origen convencional distinto al Estatuto de Roma. Los delitos de trascendencia internacional, son los que a pesar de ser crímenes con origen en convenciones internacionales, no constituyen crimen internacional propiamente dicho ${ }^{23}$, encontrando como característica "(...) del conjunto de las convenciones y tratados que regulan los "crímenes de trascendencia internacional" que no constituyen "crímenes de Derecho penal internacional" ni son parte de un "Derecho penal supranacional"; en general, sus normas no son "autoejecutables" (self'executing), sino obligaciones internacionales de diferente intensidad (según la clasificación de Virally: "invitaciones a observar comportamientos", "obligaciones de desarrollo discrecional", "obligaciones generales no concretadas", y "obligaciones concretas"), que en todo caso se encuentran necesitadas de implementación por parte de los Estados suscriptores, conforme a su propio sistema jurídico (... $)^{\prime \prime 24}$.

Los crímenes internacionales de origen convencional distinto al Estatuto de Roma son, según lo explica Ambos, “(...) esencialmente crímenes trasnacionales objeto de las, así llamadas, convenciones para la represión, tales como la Convención contra la Tortura, la Convención sobre Bombas Terroristas, o las convenciones sobre estupefacientes de la ONU"25. Además, los atentados delictivos principales (core crimes), son "los crímenes más

${ }^{21}$ Véase AMBOS, Treatise on International Criminal Law, Vol. I, Ob. cit., p. 99 y sigtes.

${ }^{22}$ Interesante análisis, en MATUS, Jean Pierre. La transformación de la teoría del delito en el Derecho Penal Internacional. Barcelona y Santiago: Atelier y Ediciones Jurídicas de Santiago, 2008.

${ }^{23}$ Véase, MATUS, Jean Pierre. La política criminal de los tratados internacionales, En: Ius et Praxis, v.13, no. 1, 2007 [en línea]. «disponible en: http:/ / www.scielo.cl/scielo. php?script=sci_arttext\&pid=S0718-00122007000100010\#nota1».

${ }^{24}$ Ibid.

${ }^{25}$ Véase, AMBOS, Kai. ¿Castigo sin soberano? Ius puniendi y función del derecho penal internacional. Dos estudios para una teoría coherente del derecho penal internacional. Bogotá: Universidad Externado de Colombia, 2013. p. 16 y 17. A su vez, acerca del fallo del Tribunal para el Líbano respecto del terrorismo, véase AMBOS, Kai. Creatividad judicial en el Tribunal Especial para el Líbano: ¿Es el terrorismo un crimen internacional?. En: Revista de Derecho Penal y Criminología, $3^{a}$ época, no. 7, enero de 2012. p. 143 y sigtes. 
graves de trascendencia para la comunidad internacional en su conjunto" y se encuentran positivizados en el Estatuto de Roma, es decir, los crímenes de genocidio, lesa humanidad, guerra y agresión ${ }^{26}$, estando caracterizados por un elemento internacional que tiene relación directa con el bien jurídico ${ }^{27}$ protegido $^{28}$.

Por supuesto, distintas discusiones se han presentado frente al carácter de internacional de estos crímenes, encontrando que contemporáneamente hay una aceptación frente al elemento contextual (chapeau/ gesamttat) respecto de los crímenes internacionales principales (core crimes) ${ }^{29}$. Frente a los elementos contextuales de los tres más desarrollados por la doctrina y la jurisprudencia, se identifica de forma general la intención de destruir, como elemento del genocidio, la sistematicidad y generalidad de un ataque, como elemento del crimen de lesa humanidad, y el conflicto armado de carácter internacional o no internacional, como elemento del crimen de guerra $^{30}$. Acorde con el concepto contemporáneo de crimen internacional, se puede afirmar que este está compuesto por dos elementos principales: el contextual y el crimen específico, sin perjuicio de la división interna que puede tener cada uno de estos dos elementos ${ }^{31}$.

${ }^{26}$ En este sentido, WERLE (Ob. cit., p. 79) afirma que "Los crímenes de guerra, los crímenes de lesa humanidad, el genocidio y el crimen de agresión son crímenes de derecho internacional. Estos así llamados "crímenes fundamentales" (core crimes) son los "crímenes más graves de trascendencia para la comunidad internacional en su conjunto"; y están sujetos a la competencia de la Corte Penal Internacional".

${ }^{27}$ Frente al concepto de bien jurídico o de legal interest, véase: AMBOS, ¿Castigo sin soberano?, Op. cit., p. 57 y sigtes. Respecto a los posible bienes jurídicos en el derecho penal internacional, véase WERLE, idem, p. 82 y sigtes.; y, en relación con los posibles intereses legales o bienes jurídicos protegidos por cada crimen, véase SATZGER, Helmut. International and European Criminal Law. München: C. H. Beck, Hart y Nomos, 2012. p. 247 y sigtes., 256 y sigtes. 264 y sigtes. Reconstruyendo la evolución de los distintos intereses legales que se han propuesto, BASSIOUNI, M. Cherif. Introduction to International Criminal Law, Second Revised Edition. Leiden y Boston: Martinus Nijhoff publishers, 2013. p. 149 y sigtes.

${ }^{28}$ En este sentido, WERLE (Ob. cit., p. 84) afirma, que "La relación con los más altos intereses de la comunidad internacional queda establecida en todos los crímenes de derecho internacional a través de un elemento común (el aquí denominado elemento internacional): todos los crímenes de derecho internacional requieren un contexto de ejercicio de violencia sistemático o masivo; la responsabilidad por el empleo de esta clase de violencia recae, por regla general, en un colectivo, normalmente en un Estado".

${ }^{29}$ AMBOS, Treatise on International Criminal Law, Vol. I, Op. cit., p. 84; WERLE, Op. cit., p. 248.

${ }^{30}$ En este sentido AMBOS, idem, p. 85.

${ }^{31}$ SATZGER, Op. cit., p. 256. 
El crimen de lesa humanidad se ha desarrollado a través de la historia ${ }^{32}$ hasta consolidar su estructura en el Estatuto de Roma ${ }^{33}$, sin perder de vista los aparentes consensos que existían con antelación al establecimiento del Estatuto de la Corte Penal Internacional ${ }^{34}$, esto es, se observa una evolución que va desde el crimen propio del conflicto armado hasta la contemporánea concepción que concibe su posible comisión en situaciones ajenas al conflicto. A su vez, frente al crimen de lesa humanidad ${ }^{35}$ establecido en el Estatuto de Roma se puede evidenciar que el elemento contextual está compuesto por un ataque ${ }^{36}$, sistemático o generalizado ${ }^{37}$, dirigido en contra de cualquier población civil ${ }^{38}$, como parte de un plan o política ${ }^{39}$ y con conocimiento de dicho ataque ${ }^{40}$. Bajo este marco normativo y conceptual, sin ánimo de profundizar en tema tan complejo, se impone entonces, confrontar las nociones anteriores con las argumentaciones de la Corte Suprema de Justicia en la sentencia objeto de análisis.

Si se lee con detenimiento el texto del proveído se puede concluir que ese organismo adopta como elementos contextuales, la sistematicidad, la generalidad del ataque, la dirección en contra de la población civil y el conocimiento como componente subjetivo de la acción. Ello evidencia, en primer lugar, que la Sala olvidó la necesidad de que se presente un plan

${ }^{32}$ La idea de este comentario no es hacer una reconstrucción exhaustiva de este punto, pero al respecto puede verse: AMBOS, Kai. Crimes against Humanity and the International Criminal Court. En: Sadat (ed.), Forging a Convention for Crimes Against Humanity, 1st ed. Cambridge: Cambrisge University Press, 2011, pp. 279 y sigtes.; AMBOS, Kai. Treatise of international Criminal Law, Volume II: The Crimes and Sentencing. Croydon: Oxford Univesrity Press, en prensa, p. 46 y sigtes.; BASSIOUNI, M. Cherif. Crimes Against Humanity, Historical evolution and contemporary application. New York: Cambridge University Press, 2011, p. 1 y sigtes.

33 AMBOS, Treatise on International Criminal Law, Vol. II, Op. cit., p. 49.

${ }^{34}$ WERLE, Op. cit. p. 462.

${ }^{35}$ Frente a la estructura del elemento contextual antes del Estatuto de Roma, véase CHARLES RUSELL, Cameron. The Chapeau of crimes against humanity, the impact of the Rome Statue of the International Criminal Court. En: Eyes on the ICC, No. 8, 25, 2011-2012, p. 28 y sigtes. [en línea] «http:/ / heinonline.org».

${ }^{36}$ AMBOS, Kai. Treatise Treatise on International Criminal Law, vol. II, Op. cit., p. 58 y sigtes.

${ }^{37}$ AMBOS, ídem, p. 59 y sigtes.; WOLFFHÜGEL GUTIÉRREZ, Christian. El elemento contextual del crimen de lesa humanidad: una visión en el marco de las decisiones de la corte penal internacional. En: BOEGLIN, Nicolás et al. (Editores). La Corte Penal Internacional una perspectiva Latinoamericana. San José: University for Peace et al., 2012, p. 2 y sigtes. [en línea]. «https://www.upeace.org/OKN/collection/ cortepenal/La $\% 20$ Corte $\% 20$ Penal $\% 20$ Internacional-Una $\% 20$ perspectiva $\% 20$ latinoamericana.pdf».

${ }^{38}$ AMBOS, Treatise on International Criminal Law, vol. II, p. 63 y sigtes.

${ }^{39}$ AMBOS, idem, p. 67 y sigtes.; WOLFFHÜGEL GUTIÉRREZ, Ob. cit., p. 8 y sigtes.

${ }^{40}$ AMBOS, Ibíd., p. 77 y sigtes. 
o política, requisito que sí toman como base el Estatuto de Roma y la jurisprudencia de la CPI, pues es un elemento esencial e intrínseco de la tipificación contenida en el artículo 7 de aquél.

Además, en segundo lugar, frente al conocimiento como componente subjetivo de la acción ${ }^{41}$ vale poner de presente que la Sentencia no diferencia entre el conocimiento de la conducta específica -como requisito exigido en todo tipo penal interno, referido solo al dolo que definen el artículo 22 del C. P. ${ }^{42}$ y el artículo 30 del Estatuto de Roma para todas las conductas constitutivas de crímenes internacionales ${ }^{43}-$, con el conocimiento del elemento contextual que expresamente exige el artículo 7 del Estatuto de Roma $^{44}$, es decir, el conocer por parte del sujeto de que se está actuando en el contexto de un ataque sistemático o generalizado, dirigido en contra de cualquier población civil, como parte de un plan o política. Ello, por supuesto, en este caso no se demostró.

Tampoco, en tercer lugar, aborda la sentencia los criterios de sistematicidad y generalidad que utiliza en el caso específico, sin quedar claro si asume alguno de los referentes internacionales o crea un criterio propio, desconociendo que a pesar de estarse generando un aparente consenso acerca de algunos elementos referidos a la positivización en el Estatuto de Roma, existen divergentes líneas de pensamiento al respecto, debiéndose destacar que la CPI maneja varias concepciones distintas a las de los tribunales Ad-Hoc. Esto, desde luego, es preocupante si se tienen en cuenta los hechos que se juzgan y la responsabilidad penal de la persona involucrada.

${ }^{41}$ En derecho penal internacional, respecto del artículo 30 del Estatuto de Roma, se discute acerca de cuál debe ser el objeto de referencia y qué connotación puede tener la referencia a elementos materiales (material elements), al respecto véase AMBOS, Treatise on International Criminal Law, vol. I, p. 270 y sigtes.

${ }^{42}$ Artículo 22 del C. P.; al respecto véase VELÁSQUEZ, Op. cit., p. 620 y sigtes.

43 "Artículo 30. Elemento de intencionalidad. 1. Salvo disposición en contrario, una persona será penalmente responsable y podrá ser penada por un crimen de la competencia de la Corte únicamente si los elementos materiales del crimen se realizan con intención y conocimiento de los elementos materiales del crimen. 2 . A los efectos del presente artículo, se entiende que actúa intencionalmente quien: a) En relación con una conducta, se propone incurrir en ella; b) En relación con una consecuencia, se propone causarla o es consciente de que se producirá en el curso normal de los acontecimientos". 3. A los efectos del presente artículo, por "conocimiento" se entiende la conciencia de que existe una circunstancia o se va a producir una consecuencia en el curso normal de los acontecimientos. Las palabras "a sabiendas" y "con conocimiento" se entenderán en el mismo sentido".

${ }^{44}$ Acerca del elemento subjetivo referente al elemento contextual, véase SATZGER, Op. cit., p. 258 y 259. Contextualizando la discusión acerca de la existencia de dos elementos subjetivos en el crimen de lesa humanidad, es decir el del artículo 7 y el del artículo 30, véase AMBOS, Treatise on International Criminal Law, vol. I, Ob. cit., p. 281. 
De la misma forma, en cuarto lugar, la providencia no asume la diferencia entre crímenes internos y crímenes internacionales -expuesta previamente-, como tampoco tiene presente que si quería tener en cuenta los crímenes del Estatuto de Roma, su valoración, por tener influencia del sistema tanto del common law como del derecho continental, es distinta.

Finalmente, en quinto lugar, se debe dejar la inquietud, por lo menos en relación con dos temas más, que tienen gran relación con lo acá tratado: de un lado, se impone referirnos a la violación del principio de legalidad y la discutible aplicación de un criterio como es el de lesa humanidad basado en el Estatuto de Roma, teniendo en cuenta que para el momento de los hechos objeto de decisión, dicho Estatuto todavía no existía, con el agravante de que el concepto utilizado por los compendios normativos previos al de Roma, manejaban estructuras distintas al concepto contemporáneo, que inclusive, exigían que los hechos se cometieran en medio del conflicto armado ${ }^{45}$.

De otro lado, se impone hacer referencia a la inclusión de elementos propios del derecho natural como fundamento de la antijuridicidad penal, puesto que la Corte alcanza a afirmar que la filosofía de los derechos humanos puede ser el fundamento de un juicio netamente jurídico, como lo es la tutela de bienes jurídicos legalmente protegidos, por medio del juicio de antijuridicidad. Ello, por supuesto, no deja de ser preocupante porque supone adoptar categorías que no tienen coherencia alguna con lo dispuesto en el Código Penal y en la propia Constitución Política.

\section{CONCLUSIONES}

De lo expresado se puede concluir, entonces, que la Sala de Casación Penal aplicó una doble subsunción de las conductas en estudio sin tener en cuenta las particularidades que genera la diferencia, tanto de la estructura típica de los supuestos de hecho como de la propia del análisis que en el Derecho penal internacional contemporáneo combina elementos de sistemas de distintas tradiciones jurídicas. Además, gracias a la doble subsunción, la providencia en examen califica las conductas como de lesa humanidad, sin tener en cuenta la estructura de los crímenes en concreto, con el único fin de darle connotaciones cualitativas como la atinente a la imprescriptibilidad; un debate difícil todavía no librado en el derecho nacional. También, a pesar de que en principio pareciera que el proveído asume el concepto del elemento contextual propio de los crímenes internacionales, la verdad es que un análisis detallado del mismo permite concluir que acoge un punto de partida que no se corresponde con los estándares internacionales en la materia. Así las cosas, esta sentencia no aprueba el examen cuando se confrontan los conceptos que emplea con las categorías propias del Derecho penal internacional; algo que, por supuesto, no debería repetirse en futuros análisis cuando se abordan tan delicadas materias.

${ }^{45}$ AMBOS, Treatise on International Criminal Law, vol. I, Op. cit., p. 47. 
En fin, muchas otras podrían decirse en relación con una decisión judicial que es fruto de una actuación violatoria del debido proceso, asume un concepto iusnaturalista de antijuridicidad y aplica de forma ilegal y simultánea dos códigos penales; y, para acabar de ajustar, que se ha producido después de una investigación que tardó veinticinco años cuando había prescrito la acción penal para dejar, de nuevo, el principio de legalidad en entredicho. Esto para no reparar en las problemáticas probatorias, algo muy difícil en el presente caso y que el proveído despachó de la forma más elusiva posible.

\section{BiBLIOGRAFÍA}

AMBOS, Kai. Observaciones a la doctrina francesa del hecho punible desde la perspectiva alemana. En: IndretPenal, 3.08, 2.008. p. 4 y 5 [en línea] «http:// www.indret.com/pdf/556_es.pdf».

-------. ¿Castigo sin soberano? Ius puniendi y función del Derecho penal internacional, dos estudios para una teoría coherente del Derecho penal internacional. Bogotá: Universidad Externado de Colombia, 2013.

--------. Creatividad judicial en el Tribunal Especial para el Líbano: ¿es el terrorismo un crimen internacional? En: Revista de Derecho Penal y Criminología, 3a época, no. 7, enero de 2012. p. 143-173.

Crimes against Humanity and the International Criminal Court. En: Sadat (ed.), Forging a Convention for Crimes Against Humanity, 1st ed. Cambridge: Cambridge University Press, 2011.

Treatise on International Criminal Law, Volume I: Foundations and General Part. Croydon: Oxford University Press, 2013.

-------. Treatise of international Criminal Law, Volume II: The Crimes and Sentencing. Croydon: Oxford Univesrity Press, en prensa.

BADAR, Mohamed Elewa. The Concept of Mens Rea in International Criminal Law: The Case for a Unified Approach. Portland: Hart Publishing, 2013.

BASSIOUNI, M. Cherif. Crimes Against Humanity, Historical evolution and contemporary application. New York: Cambridge University Press, 2011.

-------. Introduction to International Criminal Law, Second Revised Edition. Leiden y Boston: Martinus Nijhoff publishers, 2013.

BORJA JIMÉNEZ, EMILIANO. Algunos planteamientos dogmáticos en la teoría jurídica del delito en Alemania, Italia y España. En: Cuadernos de política criminal, no. 63, 1997. p. 595-652.

CHARLES RUSELL, Cameron. The Chapeau of crimes against humanity, the impact of the Rome Statue of the International Criminal Court. En: Eyes on the ICC, no. 8, 25, 2011-2012. p. 28 y sigtes. [en línea] «http:/ /heinonline.org». 
DRESSLER, Joshua. Understanding Criminal Law. Sixth Edition. San Francisco y New Providence: Lexis Nexis, 2012.

GARDNER, John. Ofensas y defensas, Madrid: Marcial Pons, 2012.

MALARINO, Ezequiel. El crimen contra la humanidad de desaparición forzada de personas en la jurisprudencia argentina: algunos problemas en relación con el principio de legalidad. En: MALARINO, Ezequiel. Derechos humanos y Derecho penal. Bogotá: Editorial Ibáñez y Pontificia Unversidad Javeriana, 2012.

MATUS, Jean Pierre. La política criminal de los tratados internacionales, En: Ius et Praxis, v.13, no.1, 2007. [en línea] «http://www.scielo.cl/scielo. php?script=sci_arttext\&pid=S0718-00122007000100010\#nota21».

La transformación de la teoría del delito en el Derecho penal internacional. Barcelona y Snatiago: Atelier y Ediciones Jurídicas de Santiago, 2008.

SATZGER, Helmut. International and European Criminal Law. München: C.H. Beck, Hart y Nomos, 2012.

VELÁSQUEZ, Fernando. Derecho penal, Parte general. 4 ed. Medellín: Comlibros, 2.009 .

WERLE, Gerhard, et al. Tratado de Derecho penal internacional. Tr. María Gutiérrez et al., 2 ed. Valencia: Tirant lo Blanch, 2011.

WOLFFHÜGEL GUTIÉRREZ, Christian. El elemento contextual del crimen de lesa humanidad: una visión en el marco de las decisiones de la corte penal internacional. En: BOEGLIN, Nicolás et al. (Editores). La Corte Penal Internacional una perspectiva Latinoamericana. San José: University for Peace et al., 2012, p. 2 y sigtes. [en línea]. «https://www.upeace.org/OKN/collection/ cortepenal/La\%20Corte $\% 20$ Penal $\% 20$ Internacional-Una $\% 20$ perspectiva $\% 20$ latinoamericana.pdf». 